\title{
Relative Sizes of Age Cohorts and Labor Force Participation of Older Workers
}

David Neumark and Maysen Yen

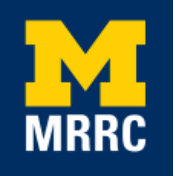

Project \#: R-UM18-08 


\title{
Relative Sizes of Age Cohorts and Labor Force Participation of Older Workers
}

\author{
David Neumark \\ University of California-Irvine, NBER, and IZA \\ Maysen Yen \\ University of California-Irvine \\ September 2018 \\ Michigan Retirement Research Center
University of Michigan
P.O. Box 1248
Ann Arbor, MI 48104
www.mrrc.isr.umich.edu
}

(734) 615-0422

\section{Acknowledgements}

The research reported herein was performed pursuant to a grant from the U.S. Social Security Administration (SSA) funded as part of the Retirement Research Consortium through the University of Michigan Retirement Research Center Award RRC08098401-10. The opinions and conclusions expressed are solely those of the author(s) and do not represent the opinions or policy of SSA or any agency of the federal government. Neither the United States government nor any agency thereof, nor any of their employees, makes any warranty, express or implied, or assumes any legal liability or responsibility for the accuracy, completeness, or usefulness of the contents of this report. Reference herein to any specific commercial product, process or service by trade name, trademark, manufacturer, or otherwise does not necessarily constitute or imply endorsement, recommendation or favoring by the United States government or any agency thereof.

Regents of the University of Michigan

Michael J. Behm, Grand Blanc; Mark J. Bernstein, Ann Arbor; Shauna Ryder Diggs, Grosse Pointe; Denise Ilitch, Bingham Farms; Andrea Fischer Newman, Ann Arbor; Andrew C. Richner, Grosse Pointe Park; Ron Weiser, Ann Arbor; Katherine E. White, Ann Arbor; Mark S. Schlissel, ex officio 


\title{
Relative Sizes of Age Cohorts and Labor Force Participation of Older Workers
}

\begin{abstract}
We study the effects of the size of older cohorts on labor force participation (LFP) and wages of older workers. In the standard relative supply framework usually applied to relative cohort size, we would expect larger older cohorts to experience lower wages and hence lower employment or LFP. However, there are two reasons that we might find a positive effect. First, we might expect the age structure of the population to affect the composition of consumption and, hence, labor demand; it is possible that the age structure of employment is such that relative labor demand for an age cohort increases when the relative size of that cohort increases. Second, a large older cohort implies that the old cohort is large relative to at least some other narrowlydefined age cohorts. If two age cohorts are substitutable, then a decline in the relative size of one of them can imply an increase in the relative demand for the other.

We use panel data on states, treating the age structure of the population as endogenous, owing to migration. We find that when older cohorts are large relative to a young cohort, the evidence fits the relative supply hypothesis. But when older cohorts are large relative to 25 to 49 year olds, the evidence points to a relative demand shift. Thus, we need a more nuanced view than simply whether the older cohort is large relative to the population; the cohort they are large relative to matters.
\end{abstract}

\section{Citation}

Neumark, David, and Maysen Yen. 2018. "Relative Sizes of Age Cohorts and Labor Force Participation of Older Workers." Ann Arbor MI: University of Michigan Retirement Research Center (MRRC) Working Paper, WP 2018-390.

https://mrdrc.isr.umich.edu/publications/papers/pdf/wp390.pdf 


\section{Introduction}

The Baby Boom and other, less-dramatic fluctuations in the sizes of birth cohorts generate substantial shifts in the relative sizes of older versus younger cohorts. Existing work on the effects of cohort size on labor markets in the United States has tended to focus on the effects of own cohort size on wages (e.g., Welch 1979), and sometimes on employment or unemployment (e.g., Korenman and Neumark 2000). These studies (as well as work for other countries, such as Morin (2015) for Canada), have tended to focus on the effects on youths of entering the labor market as part of a large cohort. In general, past studies find that youths entering the labor market as part of large cohorts fare worse - earning lower wages, and as a result having lower employment rates — at least initially. These effects are interpreted as "relative supply" or "cohort crowding" effects of a cohort's relative size, with a large cohort shifting out labor supply, depressing wages and hence employment or labor force participation rates (via the reservation wage effect). The evidence that larger cohorts experience relative earnings declines implies that workers in different age cohorts are only imperfectly substitutable, and some work (e.g., Morin 2015) suggests, as seems quite plausible, that the degree of substitutability between cohorts is lower the larger the age difference between them.

Our focus in this paper is on older workers, in particular, the effects of the size of older cohorts on their labor force participation (LFP) and wages. We concentrate on estimating effects among 50 to 59 year olds and 60 to 69 year olds. These are the age ranges in which labor force participation first starts to decline, and then when most people retire (see Appendix Table A). The 60 to 69 age range, in particular, is the age range in which, in light of population aging, policymakers are trying to increase employment, often through reforms to public pension 
systems (e.g., Gruber and Wise 2007). Moreover, this is an age range in which policy may have considerable scope for increasing LFP because of low LFP rates (see Figure 1). ${ }^{1}$

In the standard relative supply framework applied to younger workers, we would simply view larger older cohorts as likely to experience lower wages and hence lower employment or LFP. Some past work suggests we should not expect much impact of relative cohort size on older workers. For example, Welch (1979) finds evidence suggesting that the adverse effect of entering the job market in a large cohort weakens at older ages although it does not dissipate. Wright (1991), for the United Kingdom, finds that the effect fully dissipates. (However, aside from being quite dated, these studies did not focus explicitly on older individuals.) Moreover, if the degree of substitution is quite high between older cohorts and other, more-experienced workers, consistent with the flattening of earnings-experience profiles by middle age (Heckman et al. 2006), we might not expect much effect on wages or LFP of being in large cohort of older workers.

Despite these considerations, there are reasons to expect that the effects of cohort size could be sizable for older workers. Older individuals in their 50 s or 60 s have low employment rates relative to those in their $40 \mathrm{~s}$ or $30 \mathrm{~s}$, in part because of transitions to retirement, especially in the 60s (e.g., Munnell 2015). At the same time, retirement is quite fluid, because many seniors transition to part-time or shorter-term "partial retirement" or "bridge jobs" at the end of their careers (e.g., Johnson et al. 2009) or return to work after a period of retirement (Maestas 2010). Together, these facts suggest that older workers may have quite elastic labor supply on the extensive margin, in contrast to workers (especially men) of other ages, in which case the effects of large cohort size on LFP or employment stemming from wage effects, could be sizable. ${ }^{2}$

\footnotetext{
${ }^{1}$ We explored grouping the 50 to 59 year olds with 25 to 49 year olds, but the data indicated that, for the analyses we present, the behavior of 50 to 59 year-olds was similar to that of 60 to 69 year olds, and dissimilar to that of 25 to 49 year olds.

${ }^{2}$ The meta-analysis in Evers et al. (2008) points to a very low extensive margin labor supply elasticity for
} 
Moreover, if older workers in partial retirement are leaving career jobs, and perhaps taking lower-skilled or less-demanding jobs, they may not be so substitutable with prime-age workers, implying that there could be larger effects of cohort size on wages in this age range — as for young labor market entrants.

The usual relative supply hypothesis about cohort size predicts negative effects of large relative cohorts on LFP and wages. However, there are two reasons that we might find a positive effect. First, we might expect the age structure of the population to affect the composition of consumption and hence labor demand. ${ }^{3}$ It is possible that the age structure of employment is such that relative labor demand for an age cohort increases when the relative size of that cohort increases. $^{4}$

Second, a relative cohort size measure is just that — a relative measure. Thus, an increase, say, in the size of the 60 to 69 year old cohort relative to the population means that the old cohort is large relative to at least some other narrowly-defined age cohorts. If two age cohorts are substitutable, then a decline in the relative size of one of them can imply an increase in the relative demand for the other. For example, the partial/bridge retirement phenomenon may mean that "post-retirement" workers take lower-skilled jobs more similar to those held by younger workers, in which case older workers could be substitutable with young workers and a large cohort of 60 to 69 year olds relative to young workers can increase demand for 60 to 69 year olds. Alternatively, if older workers are more substitutable for workers in the prime/middle-aged cohort, we might find this positive demand response for the size of the older cohort relative to this cohort.

men generally. For evidence suggesting sizable extensive margin labor supply elasticities for older workers in the United States, see French and Jones (2012).

${ }^{3}$ For example, Reinhardt (2003, Exhibit 1) reports that per capita health spending for 55 to 64 year olds is double that for 25 to 34 year olds.

${ }^{4}$ For example, Cohen (2006) documents the aging of the U.S. nursing workforce, for which demand will surely grow as the population ages. 
We explore the effects of the relative sizes of age cohorts on LFP and wages, focusing on the effects on older individuals. We use long-term data on cohort size and cohort labor force participation rates and wages over many decades, exploiting variation across states in a panel data setting that controls for other influences on employment of older workers. We pay careful attention to the endogeneity of the contemporaneous age structure of a state's potential workforce. Given distinct and persistent patterns of internal migration related to age (e.g., migration to Florida and Arizona), as well as more variable changes in internal migration with respect to economic conditions and international immigration, we might expect the effects of the relative sizes of different age cohorts to be hard to detect in OLS estimates. For example, an adverse effect of a large cohort on LFP may be obscured because the cohort is large owing to inmigration in response to strong labor demand. We instrument for contemporaneous relative cohort size measures using historical birth data by state and cohort, which should be an exogenous source of variation in states' current demographic structures.

Future employment rates of older individuals are important determinants of the financial solvency of Social Security, mainly because higher employment implies a continued inflow of Social Security payroll taxes. For example, assumptions about LFP by age play a key role in the 2016 annual report of the federal OASDI and DI trust funds. ${ }^{5}$ More controversially, perceptions about the appropriate earliest age of eligibility for claiming Social Security benefits, and the adequacy of benefit levels at that age, hinge in part on employment prospects of individuals at those ages. Thus, knowing what changing demographic structure implies for the likelihood of employment at older ages can inform our understanding of the solvency of Social Security and of policies that might be adopted to strengthen it.

\footnotetext{
${ }^{5}$ See https://www.ssa.gov/oact/tr/2016/tr2016.pdf, Chapter V.B.5 (viewed April 18, 2017).
} 


\section{Relevant Prior Work}

There is long-standing interest in factors affecting the employment of older workers, often motivated by implications for retirement systems. Perhaps the largest body of research focuses on work incentives created by the Social Security system itself, including the level of benefits (e.g., Burtless 1986), the early retirement age (e.g., Gustman and Steinmeier 2005), the structure of the earnings test (e.g., Friedberg 2000), and the impact of reforms to delay retirement (e.g., Neumark and Song 2013).

Research has also focused on other factors affecting employment of older workers. For example, there has been an outpouring of research on factors that appeared to have slowed the growth in employment and labor force participation of older workers since the Great Recession, such as changes in age discrimination (Neumark and Button 2014) and increases in SSDI awards (Mueller et al. 2016).

The effect of the relative sizes of age cohorts on the LFP of older individuals is a potentially important factor to study, for at least two reasons. First, variation in cohort size can be used to improve predictions of long-run changes, because the sizes of age cohorts can be quite reliably projected far into the future.

Second, past research on the effects of cohort size on young workers establishes that cohort size can be influential. Welch (1979) showed that within schooling groups, the large cohort size of Baby Boomers reduced wages, with a larger impact on highly-educated workers and workers early in their career. ${ }^{6,7}$ Korenman and Neumark (2000) study variation over countries and across

\footnotetext{
${ }^{6}$ Welch's study, like many others on cohort size, focuses on wages, but the effects of cohort size on wages should translate into effects on employment and LFP rates, with lower wages reducing these rates, and vice versa. Berger (1984) follows up on Welch's work by looking at effects on earnings profiles, which he interprets as reflecting human capital investment. This channel of influence is less relevant for older workers.

${ }^{7}$ Macunovich (1999) tried to separate labor supply and labor demand effects of cohort size, suggesting that relative sizes of birth cohorts (and changes in birth cohorts, to capture leading and lagging effects of a
} 
time to estimate the effect of the relative size of youth cohorts on youth unemployment rates. Like the strategy we use in this paper, they use an instrumental variables approach based on births by cohort and country to account for the endogeneity of cohort size with respect to labor market conditions (via migration), and when doing so find that larger youth cohorts are associated with higher unemployment rates.

We do not focus only on the relative cohort size of the cohort of interest — in this case, older individuals - but also on a more detailed characterization of the sizes of other cohorts in different age ranges. This can matter because substitutability between cohorts may vary with "distance" in age. One paper that pays more attention to sizes of multiple cohorts is Stapleton and Young (1988), although they focus more on incentives to invest in education owing to how substitutability between cohorts varies by education, a question farther removed from the focus of our paper. Our research also differs in focusing on how cohort size affects LFP (and wages) of older individuals.

\section{Empirical specifications and strategy}

We begin with a specification used to estimate the effects of a large cohort of older individuals on their LFP. This specification takes the form:

$$
\mathrm{LFP}^{\mathrm{O}}{ }_{\mathrm{st}}=\alpha+\beta^{\mathrm{O} / \mathrm{T}} \mathrm{RCS}^{\mathrm{O} / \mathrm{T}}{ }_{\mathrm{st}}+\mathrm{X}_{\mathrm{st}} \gamma+\lambda_{\mathrm{s}}+\theta_{\mathrm{t}}+\varepsilon_{\mathrm{st}} .
$$

The $\mathrm{O}$ superscript denotes older cohorts aged either $50-59$ or $60-69$. RCS is a relative cohort size measure, and the $\mathrm{O} / \mathrm{T}$ superscript denotes this that is computed for older cohorts relative to all working-age cohorts (16 to 69$)$. $\mathrm{X}$ is vector of controls including: the

boom) affect supply, while relative sizes of current cohorts (and changes) reflect demand. It is not clear why this distinction isolates supply and demand effects; indeed, we use data on births to construct instrumental variables for contemporaneous cohort sizes, without taking a position on whether births drive supply or demand. 
unemployment rate for 16 to 69 year olds, ${ }^{8}$ the rate of state GDP growth from the previous year to the current one; the shares married, female (when we estimate regressions for men and women combined), Hispanic, black, urban, and union members; and the shares with less than a high school degree and a bachelor's degree or higher. The $s$ and $t$ subscripts denote state and year, and $\lambda_{\mathrm{s}}$ and $\theta_{\mathrm{t}}$ are vectors of fixed state and year effects. LFP is the state-by-year average. The LFP and RCS variables are entered in logs, so $\beta^{\mathrm{O} / \mathrm{T}}$ is an elasticity. Because we use sample estimates of state-level averages to construct our data, we always use generalized least squares, weighting by average state population measured over the sample period. Our IV estimates (described below) are similarly weighted. We also estimate versions of equation (1) for the state-by-year log of average hourly wages.

The estimate of $\beta^{\mathrm{O} / \mathrm{T}}$ measures the impact of the size of the older cohort relative to the workforce on LFP (or wages) of that older cohort. We would expect similar qualitative results for cohorts of other ages, viewed through the simple mechanism of supply shifts. We also estimate equation (1) for younger cohorts (age 16 to 24, denoting the cohort size variable $\operatorname{RCS}^{\mathrm{Y} / \mathrm{T}}$ ), and prime-aged cohorts (ages 25 to 49 , denoting the cohort size variable $\mathrm{RCS}^{\mathrm{P} / \mathrm{T}}$, and the corresponding coefficients $\beta^{\mathrm{Y} / \mathrm{T}}$ and $\beta^{\mathrm{P} / \mathrm{T}}$ ).

The relative cohort size measures may be endogenous. One possibility is that people migrate to where labor market conditions for their age group are better. This would create a bias against finding evidence, predicted by the relative supply hypothesis, that a larger relative cohort size reduces LFP or wages, as the cohort size may expand in response to high labor demand (which boosts LFP and wages). We might expect this kind of migration to be more common for younger cohorts.

In contrast, older individuals may be more likely to migrate for retirement-related reasons. States that are retirement destinations will tend to have larger relative older cohort sizes but

\footnotetext{
${ }^{8}$ This is defined for men, women, or both sexes, depending on the sampled used.
} 
lower LFP rates, not because of cohort-size effects on labor supply, but through selective inmigration of older retirees. And similarly, states from which retirees (or near-retirees) migrate will tend to have lower relative cohort sizes at older ages, but high LFP, because of selective outmigration of retirees. The endogeneity bias from retirement-induced migration is, thus, in the opposite direction to the endogeneity bias from employment-induced migration — with retirement-induced migration biasing the evidence in favor of the relative supply hypothesis. Of course, it is possible that some older people migrate based on labor market conditions if they entertain the possibility of some "post-retirement" work, so the direction of bias is ultimately an empirical question. In contrast to LFP, there is no clear prediction about bias in the estimates of equation (1) for wages — for older cohorts — from retirement-related migration.

Migration flows seem to be large enough to matter, and this is borne out in our instrumental variables estimates. Appendix Figures A1-A4 show data on interstate in-migration rates for retirement-related and work-related reason based on Current Population Survey (CPS) Annual Social and Economic Supplement (ASEC) data. Appendix Figure A1 shows data for 60 to 69 year olds, with states ordered by retirement related in-migration rates. The states near the top of this list — such as Arizona, Florida, and Nevada — are unsurprising. For these states, the one-year in-migration rates are near 0.4 percent. Thus, interstate in-migration could, over a number of years, result in sizable changes in the cohort share. We see, by the way, a good deal of work-related interstate migration reported for this age group, suggesting that it is unclear what the direction of bias might be when we estimate equation (1) for the older cohort; this depends on both the magnitudes of the migration flows, as well as their endogeneity.

Appendix Figure A2 shows the data 50 to 59 year olds. There is less retirement-related migration for this age group; for the states with the highest rates, the level is about half $(0.2$ percentage points) what it is for 60 to 69 year olds. Interestingly, also, the states for which 
retirement-related migration is highest are somewhat different than for 60 to 69 year olds. For 50 to 59 year olds, far more migration is work related.

Appendix Figures A3 and A4 show the data for the other two cohorts, now with states ordered by work-related in-migration rates. There is, not surprisingly, very little retirementrelated migration for these age cohorts. But work-related in-migration rates are often quite high, with one-year rates well above one percent for 25 to 59 year olds, and 1.5 percent for 16 to 24 year olds. Thus again, over many years, in-migration could have substantial effects on the cohort share.

To address the potential endogeneity of relative cohort size, we instrument for the relative cohort size variables using predicted relative cohort sizes based on past births in the state for the years in which members of a cohort would have been born. Thus, for example, the instrumental variable for $\mathrm{RCS}^{\mathrm{O} / \mathrm{T}}$ in 2000 - the ratio, in 2000 , of the number of people currently in the state aged 60 to 69 , divided by the number aged 16 to 69 - is the ratio of the number of people born in the state between 1931 and 1940, to the number of people born in the state between 1931 and 1984. The logic of this instrumental variable is clear. The relative birth-cohort size instrument should predict the contemporaneous relative cohort size quite well, and it does. It is hard to fathom a reason why the relative birth-cohort size instrument - often constructed from very long lags — would affect current labor market outcomes conditional on the contemporaneous relative cohort size variable, satisfying the exclusion restriction. ${ }^{9}$ Thus, the relative birth-cohort instrument should purge the contemporaneous relative cohort size variable of variation attributable to migration. (It should also help correct for other sources of bias, such as measurement error in the estimation of the contemporaneous relative birth cohort variables; the

\footnotetext{
${ }^{9}$ As indirect evidence, we verified that our instrumental variable does not predict contemporaneous state GDP growth, whether or not we condition on the contemporaneous relative cohort size variable. This holds true across age groups, and in the richer specifications described below with two relative cohort size variables and two instrumental variables. (Results available upon request.)
} 
latter are estimated from the CPS, whereas the birth cohort variables are constructed from the universe of birth records.)

The standard expectation, based on the relative supply hypothesis regarding cohort size, is that the effects of $\mathrm{RCS}^{\mathrm{O} / \mathrm{T}}$ on both wages and LFP will be negative, and similarly for $\mathrm{RCS}^{\mathrm{Y} / \mathrm{T}}$ and $\operatorname{RCS}^{\mathrm{P} / \mathrm{T}}$ when we look at the younger cohorts. However, if older cohorts have more elastic extensive margin labor supply responses, we might find larger negative estimates of $\beta^{\mathrm{O} / \mathrm{T}}$ than $\beta^{\mathrm{Y} / \mathrm{T}}$ or $\beta^{\mathrm{P} / \mathrm{T}}$. In contrast, effects could go in the other direction because of effects of age structure on the age composition of labor demand, or because of substitution between workers in different age cohorts.

We also explore whether the effects of age structure on LFP and wages of older workers are more complex than simply an effect of their cohort size relative to the working age population, owing to more complex spillovers between cohorts of different ages. These complexities could arise through the demand side, depending on how the relative sizes of other cohorts affects demand for older workers. They could also arise through the supply side, as a large relative cohort of older workers could be driven by a smaller cohort of very young workers, or of prime/middle-aged workers, and there may be different degrees of substitutability between these cohorts and older workers.

To address this question, we modify equation (1) and instead estimate a model with separate effects of the size of the older cohort relative to the two younger age cohorts:

$$
\mathrm{LFP}_{\mathrm{st}}^{\mathrm{O}}=\alpha+\beta^{\mathrm{O} / \mathrm{Y}} \mathrm{RCS}_{\mathrm{st}}^{\mathrm{O} / \mathrm{Y}}+\beta^{\mathrm{O} / \mathrm{P}} \mathrm{RCS}^{\mathrm{O} / \mathrm{P}}{ }_{\mathrm{st}}+\mathrm{X}_{\mathrm{st}} \gamma+\lambda_{\mathrm{s}}+\theta_{\mathrm{t}}+\varepsilon_{\mathrm{st}}{ }^{10}
$$

The estimate of $\beta^{\mathrm{O} / \mathrm{Y}}$ captures the effect of the size of the older cohort relative to the younger cohort, and the estimate of $\beta^{\mathrm{O} / \mathrm{P}}$ captures the effect of the older cohort's size relative to

\footnotetext{
${ }^{10}$ We verified that estimating equation (1) for the size of the 60 to 69 cohort or the 50 to 59 cohort relative to the combined 16 to 59 or 16 to 49 cohort (respectively) yields very similar results to defining the size of the older cohorts relative to 16 to 69 year-olds. Thus, the difference in results we report from equation (2) has only to do with differences in the sizes of the older cohorts relative to the 16 to 24 or 25 to 49 cohorts.
} 
the prime-aged cohort. ${ }^{11}$ Equation (2) can tell us, for example, whether the effect of a large older cohort on LFP varies with whether the older cohort is large relative to the cohort of workers distant in age (i.e., the young), or the cohort of those closer in age.

We also address endogeneity bias in equation (2). Indeed, differential responsiveness of migration across age groups could be particularly problematic in estimating equation (2). For example, suppose there is strong retirement-related migration of older individuals. We would not expect any such response among the younger cohort; in contrast, there could be at least some retirement-related migration in the prime-age group. In that case, the negative correlation between $\varepsilon^{\prime}$ and $\mathrm{RCS}^{\mathrm{O} / \mathrm{Y}}$ in equation (2) could be particularly strong. We use the same overall strategy, but now using two instrumental variables for the two relative cohort size variables in equation (2). For example, the instrumental variable for the $\mathrm{RCS}^{\mathrm{O} / \mathrm{Y}}$ in 2000 - the ratio of the number of people currently in the state ages 60 to 69 in 2000, divided by the number ages 16 to 24 - is the ratio of the number of people born in the state between 1931 and 1940, to the number of people born in the state between 1976 and 1984. And the instrumental variable for the $\mathrm{RCS}^{\mathrm{O} / \mathrm{M}}$ in 2000 - the ratio of the number of people currently in the state ages 60 to 69 in 2000 , divided by the number ages 25 to 59 - is the ratio of the number of people born in the state between 1931 and 1940 to the number of people born in the state between 1941 and 1975 .

\section{Data}

Our contemporaneous population and LFP data come from the Census Population Survey (CPS) monthly basic files, from 1977-2016. ${ }^{12}$ The microdata are aggregated to create state-byyear measures. Cohort sizes are constructed by weighting individuals by the survey weights used to aggregate up to population estimates, to make the estimates population representative.

\footnotetext{
${ }^{11}$ From here, we use "prime" to refer to ages 25 to 49 . This is not meant to reflect a judgement about age. But use of "middle-aged" for 25 to 49 year olds is likely to create more confusion.

${ }^{12}$ Our data come from the Integrated Public Use Microdata Series (Flood et al. 2017)
} 
For example, for the oldest cohort of 60 to 69 year olds, RCSO/Tst is constructed by taking the sum of the survey weights in state $s$, at time $t$, for ages 60 to 69 divided by the sum of the survey weights in state $s$, at time $t$, for the entire 16 to 69 age group. LFP rates are constructed using the same survey weights.

Wage data come from the CPS merged outgoing rotation group (ORG) files, which are available from 1979. The hourly wage is measured directly as earnings per hour when available (for those paid hourly). Otherwise, it is constructed by dividing earnings per week by the usual hours worked, for those who are not paid by the hour. ${ }^{13}$ The computed hourly wages are trimmed by removing hourly wages below half the state minimum wage or above $\$ 200 /$ hour (in 2016 dollars). Hourly wages are then averaged by state and year, using the survey weights.

The instrumental variables construction was considerably more involved. We use historical series on births by states, based on U.S. Vital Statistics reports published by the National Center for Health Statistics (NCHS). The data are available in two forms, either through Births: Final Data ${ }^{14}$ reports retrievable online from 1970, or in U.S. Vital Statistics Reports (both reports are typically published two years after the reported year). The U.S. Vital Statistics Reports have been produced since 1890, although birth information was not captured until 1915 when 10 states and the District of Columbia adopted the birth-registration system (National Office of Vital Statistics 1968). Other states began to trickle in with the final states being Texas in 1933 and then Alaska in 1945 (see Appendix Table B). The Births: Final Data series is more recent. It started in 1971 and was published concurrently with the U.S. Vital Statistics Reports, but the latter was phased out by 2003. The two reports are not completely

\footnotetext{
${ }^{13}$ Observations are not used if earnings are not reported, or if only weekly earnings, but not hours, are reported.

${ }^{14}$ Births: Final Data for (various years) is the series title for the reports from 1997 to 2015 . There are other names prior to this, such as Report of Final Natality Statistics, (various years), Advance Report of Final Natality, and Statistics, (various years). But we refer to these all as Births: Final Data.
} 
identical, but do not have large discrepancies. ${ }^{15}$ We use the reported numbers of births in the Births: Final Data reports as our source back to and including 1971, and the U.S. Vital Statistics Reports for prior years back to $1931{ }^{16}$ Prior to 1931, the number of births is not available, so we reconstructed the level from the crude birth rates, defined as the number of births per 1,000 population. $^{17}$

There is surely some measurement error in the birth instruments we construct. And the accuracy of reporting is worse in the earlier data. For example, our constructed number of births from 1915 to 1930 from crude birth rates and estimated population sizes suggests a sharp decrease in the number of births from 1930 to 1931, which implies we overstated the number of births from 1915 to 1930 . This is likely because crude birth rates are inconsistent due to unclear adjustments for under-registration. ${ }^{18}$ For example, the crude birth rates from 1915 to 1929 do not have birth rates adjusted for under-registration, while the 1930 to 1940 crude birth rates had an adjustment for under-registration. Overall, the general issues with crude birth rates contributed to our decision to use the number of births from the individual yearly files either from Births: Final Data or U.S. Vital Statistics Reports, whenever available.

Despite these concerns, measurement error in instrumental variables is of less concern than measurement error in the variables of interest. Indeed, if the measurement error in the

\footnotetext{
${ }^{15}$ This is based on personal communications with Michelle Osterman, a Health Statistician at NCHS (5/2/17 and 5/8/17). The Births: Final Data series is easier to navigate and seems to be cited more often. ${ }^{16}$ One exception is the year 1979, in which the final report is not available online. For this year, we use the U.S. Vital Statistics Report birth numbers.

${ }^{17}$ Vital Statistics Rates in the United States 1900-1940 contains birth rates and estimated population sizes for 1915 to 1930, which allows us to estimate the number of births

${ }^{18}$ In general, these earlier adjustments to crude birth rates are not well documented or transparent other than the dates of the adjustments. The most egregious example is that the crude birth rates recorded for 1940 are different between Vital Statistics in the United States, 1900-1940 and Vital Statistics in the United States, 1940-1960. Michelle Osterman and her colleague, Brady Hamilton, were unable to reconcile this difference, but believe the more recent Vital Statistics in the United States, 1940-1960 is accurate (personal communication, 5/8/17).
} 
instrument is uncorrelated with the variable(s) for which we are instrumenting, and uncorrelated with the error term in the equation of interest, the measurement error does not introduce any inconsistency in the instrumental variables estimation, although it can weaken the instrument and make the instrumental variables estimate less precise. This is true even if the measurement error is worse in earlier periods (i.e., heteroskedastic). Therefore, while we note these potential issues with the early birth data, we do not believe these issues pose substantive challenges to our empirical analysis. ${ }^{19}$

To have data on the birth instrument for the oldest people in our sample (age 69), we shorten the CPS panel we use to begin in 1984, rather than 1977 (for LFP) or 1979 (for wages). Even then, our panel with the instrument is unbalanced because we do not have the requisite birth data for all states from the earliest year, due to when the states started reporting births. However, there are no gaps between years. For example, in 1984, there will be 10 states and D.C. available since the number of births in the old cohort is drawn from the number of births in years 1915 to 1924 . For later years, more states are added as their number of births are reported. For example, Georgia, which first started collecting birth data in 1928, will be first be available in 1997, when the number of births for 69 year olds is recorded.

\section{Results}

\section{Descriptive statistics}

Figure 1 shows LFP rates by age group, and Figure 2 shows population shares. We do not want to infer much from these aggregate time series, ${ }^{20}$ but we see that the rise in LFP of 60 to 69

\footnotetext{
${ }^{19}$ Perhaps reflecting this, when we estimated all of our models without weighting, the OLS estimates were typically very similar to the (weighted) GLS estimates. The unweighted instrumental variables (IV) estimates were often quite similar, but sometimes less so, typically in cases where the standard errors of the unweighted IV estimates were much larger, in some cases by a factor of five or more.

${ }^{20}$ One potential advantage of the national time-series data, relative to more disaggregated data, is that it should not be influenced by bias from endogenous migration across states.
} 
year olds in the latter part of the sample period (Figure 1) coincides with an increase in their relative cohort size (Figure 2). ${ }^{21}$ On the surface, this is inconsistent with the usual relative supply cohort size hypothesis in which a large cohort size depresses LFP. Moreover, Panel D of Figure 4 (discussed in more detail below) shows that the rising LFP of the older cohort was accompanied by rising real wages, ${ }^{22}$ also inconsistent with the relative supply hypothesis.

We next explore the relationships between LFP, wages, and relative cohort size in more detail, providing similar evidence for different age cohorts, and showing both the time-series and the within-state variation and covariation between these three variables. First, what do the time series on LFP and cohort size for the other age cohorts show? To avoid having to compare across Figures 1 and 2, Figure 3 graphs the time series on LFP rates and relative cohort size for each of the four age cohorts. Panel A of Figure 3 - for 16-24 year-olds — parallels the evidence for 60-69 year-olds in that LFP rates and relative cohort size tend to move in the same direction, rather than the opposite direction as predicted by the relative supply hypothesis. The evidence for 25-49 and 50-59 year-olds is less clear.

Figure 4 shows the same type of evidence, but for real wages. Here, the evidence for the younger cohorts is mixed. The evidence for 25-49 year-olds shows rising wages in the latter part of the sample period, when relative cohort size is declining — consistent with the relative supply effect of cohort size. However, in the earlier part of the sample, wages are flat as relative cohort size rises. And the correlation is negative, as reported in the notes to the figure. For 16-24 yearolds, in contrast, the wage and relative cohort size series track each other in the early part of the sample, which is inconsistent with the relative supply effect of a larger cohort, and then both series are largely flat subsequently. The correlations for this age group, as well as the two older cohorts, are positive; see the figure notes.

\footnotetext{
${ }^{21}$ The correlation is 0.595 .

${ }^{22}$ The correlation is 0.627 .
} 
The next two figures instead provide information on changes over time at the state level, providing scatter plots of the 1977 to 2016 changes (1979 to 2016 for wages) for each state. Thus, the data points summarize the overall changes over the sample period, in contrast to the year-by-year changes graphed for the aggregate time series. In Figure 5, for LFP rates and relative cohort size, there is evidence of negative relationships for all four age cohorts -16 to 24, 25 to 49,50 to 59 , and 60 to 69 - although the slope coefficient is particularly large for 16 to 24 year olds $(-0.979)$ and near zero for 50 to 59 year olds. (The correlation is only statistically significantly different from zero for 16 to 24 year olds.) These contrast with the positive correlations in the time-series data shown in Figure 3 and are more consistent with the relative supply effect of cohort size. In Figure 6, we find evidence of a positive relationship for 16 to 24,25 to 59 , and 25 to 59 year-olds, inconsistent with the relative supply effect of cohort size, while the evidence for 60 to 69 year olds is more consistent with this effect.

Thus, the time-series evidence is largely inconsistent with the relative supply effect of cohort size (Figures 3 and 4). The state-level evidence for LFP is consistent with this effect for all age cohorts (Figure 5), while in three out of four cases, the evidence for wages is not (Figure 6). However, this evidence is suggestive at best, and the state-level evidence may be particularly prone to endogeneity bias, with the bias for the older cohorts, for LFP, likely in the negative direction. Hence, we next turn to the regression estimates, with the instrumental variables (IV) estimates most likely to uncover the true effects of relative cohort size.

\section{LFP: OLS regression estimates}

Table 1 reports OLS regression estimates of the effects of relative cohort size on LFP, for each age group, for both sexes combined, and then for men and women separately; these are estimates of equation (1). For both sexes combined, we find a positive and significant effect of relative cohort size for 16 to 24 year olds, with an elasticity of 0.097 . The estimate for 25 to 49 year olds is also positive, but smaller (an elasticity of 0.039 ), and similarly for 50 to 59 year olds 
(an elasticity of 0.049 ). For the oldest cohort, aged 60 to 69 , the estimate is significant and negative, with a larger absolute estimated elasticity $(-0.134)$. The sign pattern of the estimates is almost always the same for men and women separately (there is one exception, for 25 to 49 year old men). In addition, some of the estimates for men and women separately are smaller than the estimates for both sexes combined and not always statistically significant.

The negative estimates for the oldest cohort are consistent with the relative supply effect of a larger cohort. The positive estimates for two younger cohorts and the older (50 to 59) cohort are not. Recall, though, that there is a potential positive bias in the estimates for cohorts for which migration is more related to labor market conditions — with in-migration to areas with stronger labor demand, boosting both relative cohort size and LFP. At the same time, the estimates for the older cohorts could be biased in the opposite direction from retirement-related endogenous migration.

\section{LFP: IV estimates}

Table 2 reports the IV estimates of equation (1) for LFP. Recall that constructing the IV causes us to lose the earliest years of the sample (plus some other earlier observations for some states). Thus, in Table 3 we first report OLS estimates for the same sample for which we can do the IV estimation. The OLS estimates are largely consistent with Table 1. For both sexes combined, we continue to find a positive and significant effect for the youngest cohort, a weaker positive effect for the 50- to 59-year-old cohort, and a negative and significant effect for the oldest cohort. For 25 to 49 year olds, however, the estimate is now negative. For men and women separately, the sign pattern is always the same, but the estimates are less often statistically significant.

The IV estimates tell a strikingly different story. For the two younger cohorts (16 to 24 and 25 to 49), the IV estimates point to a significant, negative effect of relative cohort size on LFP. This is true for men and women combined, and for each sex separately. The estimated 
elasticities range from -0.101 to -0.434 . These estimates are consistent with the standard relative supply hypothesis about the effect of relative cohort size. In every case (six estimations) the direction of change relative to the OLS estimates is consistent with positive bias induced by in-migration to stronger labor markets.

In contrast, for the two older cohorts (50 to 59 and 60 to 69 ) we find strong evidence of a large positive effect of relative cohort size, for both sexes combined, and for men and women separately. The estimated elasticities range from 0.253 to 0.857 . This evidence is inconsistent with the relative supply effect of a large cohort, and instead suggests that there are labor demand effects from large older cohorts that more than offset any supply effects. As for the two younger cohorts, the IV estimates are quite different from the OLS estimates. However, for the older cohorts the direction of the change relative to the OLS estimates is in every case (again, six estimations) consistent with negative bias in the OLS estimates from endogenous migration related to retirement. Thus, the IV versus OLS estimates are consistent with the kinds of biases we might expect — job-market related for younger cohorts, and retirement related for older cohorts.

Table 2 also presents additional information about the IV estimates. First, in each panel we report the reduced-form estimates - the effects on LFP of the relative cohort size variables defined based on births only. These always share the sign and significance of the IV estimates. ${ }^{23}$ Next, we report the first-stage coefficient estimates and F-statistics. The first-stage estimates are always positive and strongly statistically significant. The magnitudes are generally in the 0.2 to 0.4 range. The F-statistics are very large, ranging from 26 to 173 . Finally, we report p-values from the Durbin-Wu-Hausman endogeneity test. These p-values are always below 0.02 , and in most cases are below 0.01 , indicating significant evidence of endogeneity bias.

\footnotetext{
${ }^{23}$ Sometimes the significance level varies, but the same estimates are significant at 10-percent or less.
} 
Wages: OLS regression estimates

We next turn to estimates of equation (1) for the effects of relative cohort size on wages. As reported in Table 3, for both sexes combined, we find a negative and significant effect of relative cohort size for 16 to 24 year olds, with an elasticity of -0.058 . In contrast, for 25 to 49 year olds the estimate is large and positive (an elasticity of 0.216 ). For the two older cohorts (50 to 59 and 60 to 69 ) the estimates are negative, fairly small, and statistically significant only for 50 to 59 year olds (elasticity of -0.057 ). The sign pattern of the estimates is the same for men and women separately. For the analysis of wages, the OLS estimates are clearer in indicating support for the relative supply effect of a larger cohort, as most of the estimates are negative (although not for 25 to 49 year olds).

\section{Wages: IV estimates}

Table 4 reports the IV estimates for wages. There are less clear expectations regarding endogeneity bias in the estimated effects of relative cohort size on wages. First, while the younger and prime-aged cohorts may migrate to strong labor markets, the outward supply shift in these states may not do much to lower wages, and there can be offsetting effects from, agglomeration externalities and/or compensating differentials for congestion (e.g., Richardson 1995). Second, for the older cohorts, as noted above, there is no clear prediction about bias from retirement-related migration.

The OLS estimates for the sample for which we can do IV are partly, but not fully, consistent with Table 3. In the estimates for both sexes combined, we continue to find a positive and significant estimate for the 25- to 49-year-old cohort and no effect for the oldest cohort (60 to 69). But for the youngest cohort, the estimates are now always insignificantly different from zero (and slightly positive), and for the 50- to 59-year-old cohort the estimate is near zero and not statistically significant. In the estimates for men and women separately, all of the estimates are positive, but small and not statistically significant. 
In the IV estimates, we again get a sharp message. For the two younger cohorts, there is evidence of a positive effect of relative cohort size, for the men and women combined and for men. The elasticities range from 0.19 to 0.44 and are always statistically significant (one at the 10-percent level). For the two older cohorts, in contrast, the IV estimates always point to a negative effect (significant in all cases but one), which is consistent with the relative supply effect of a large cohort. The elasticities range from -0.17 to -0.60 .

Like Table 2, Table 4 also reports diagnostic information about the IV estimates. The firststage results are the same as for the LFP estimates, and hence are not reported again (see Table 2). The reduced-form estimates always share the sign and significance of the IV estimates. And the p-values from the Durbin-Wu-Hausman endogeneity test indicate evidence of endogeneity bias, although in two cases the p-values are around 0.1 . Thus, although we did not have strong $a$ priori expectations of endogeneity bias in wage estimates, the evidence suggests there is such bias.

As it stands, then, the evidence on the estimated effects of a larger cohort on wages are in contradiction to the estimated effects on LFP. For the older cohorts, the LFP effects point to a positive demand shift toward older workers when the older cohort is larger, while the wage effects are most consistent with a negative relative supply effect. In contrast, for the younger cohorts the LFP effects are most consistent with a negative relative supply effect, while the wage effects are in the opposite direction.

\section{Separate effects of older cohort size relative to younger or prime-aged cohort}

When we estimate the richer model (equation 2) allowing for separate effects of the size of the older cohort relative to the two younger cohorts, we obtain a more coherent set of findings. These estimates are reported in Tables 5A (for 50 to 59 year olds) and 5B (for 60 to 69 year olds). Here, we report the OLS and IV estimates for the consistent sample for which we can compute both. 
The IV estimations in Tables 5A and 5B are more demanding because there are now two endogenous variables. The first-stage F-statistics are fairly large in both tables, ranging from 17.1 to 54.2. But with multiple instruments the preferred diagnostic is Shea's Partial $\mathrm{R}^{2}$. There is not a clear interpretation of these partial $\mathrm{R}^{2}$ values. But to give some idea, Stock and Yogo (2005) provide tables of critical values to use for the minimum eigenvalue in cases of multiple instruments when errors are i.i.d. and there is no weighting. Although these do not apply here, both because we weight and because we use heteroskedasticity-robust standard errors, it is instructive to look at the Stock and Yogo results if we drop the weighting and treat the standard errors as homoscedastic. For the 60- to 69-year-old women-only specifications, the minimum eigenvalue is $0.44 .^{24}$ This is well below the critical values even if we were to allow relatively high percent bias in the 2SLS estimate of the coefficient of the endogenous variable, and a much larger size of the Wald test for this 2SLS estimate compared to a nominal 5 percent size. For example, even with 30 percent relative bias and 25 percent size, the Stock and Yogo critical value for the minimum eigenvalue is 3.63 , well above the actual 0.44 value. In contrast, for the 60 to 69 year-olds pooled estimates and the estimates for men only, the minimum eigenvalues are 4.88 and 7.68, respectively, which are both above the critical value for 10-percent test size and the men only minimum eigenvalue is above the 5-percent test. Thus, only for these cases would we regard the IV estimates as informative. For the 50 to 59 year olds, the minimum eigenvalues range from 0.07 to 0.14 , all well below the critical values, suggesting that the IV estimate may not be very informative.

As it turns out, however, the IV results are qualitatively similar for all three samples pooled, men only, and women only. (Recall earlier that we noted that IV estimates without weighting were much less precise. The implication is presumably that the IV's are stronger than indicated by the Stock and Yogo analysis based on unweighted estimates.) For LFP, we find a

\footnotetext{
${ }^{24}$ It is the same for the LFP and wage equations, because the first stage is the same.
} 
weak negative effect or no effect of the size of the 50- to 59-year-old cohort relative to the youngest cohort (16 to 24 ), with elasticities ranging from 0.004 to -0.089 . But for the size of the older cohort relative to the prime-aged cohort (25 to 49 ), the estimated effect is strongly positive in all three cases; the elasticities range from 0.19 to 0.42 .

For wages, the effect of the size of the 50- to 59-year-old cohort relative to the youngest cohort is negative but not statistically significant, with elasticities ranging from -0.11 to -0.20 . The estimated effect of the size of the older cohort relative to the prime-aged cohort is more strongly negative, and statistically significant in all cases, with elasticities ranging from -0.33 to -0.35 .

Table 5B presents similar estimates, for the oldest cohort of 60 to 69 year olds. Turning immediately to the IV estimates, the sign pattern is identical to that for 50 to 59 year olds. For LFP, the results are stronger. There is a large negative effect of the size of the 60- to 69-year-old cohort relative to the 16 - to 24 -year-old cohort, with elasticities ranging from -0.46 to -0.51 . And there is a large positive effect of the size of the 60- to 69-year-old cohort relative to the 25 to 49 -year-old cohort, with elasticities ranging from 0.51 to 0.95 . For wages, only the estimated effect of cohort size relative to 16 to 24 year olds is statistically significant with elasticities ranging from -0.24 to -0.31 .

Interestingly, then, when we look at the size of the two older cohorts (50 to 59 and 60 to 69) relative to the youngest cohort (16 to 24), the evidence is essentially fully consistent with the relative supply effect of a larger cohort - with negative effects on both LFP and wages. ${ }^{25}$ In contrast, when we look at the size of the older cohorts relative to the prime-aged cohort (ages 25 to 49), there is relatively little statistical evidence for the relative supply effect of a larger older cohort. The LFP effect is positive for both older cohorts (in Tables 5A and 5B), and the wage

\footnotetext{
${ }^{25}$ The only exception is the LFP estimate for women, which is 0.004 . But there is no contradiction between the LFP and wage results, unlike what we had earlier, with opposite-signed effects.
} 
effect is not significant for 60 to 69 year olds in Table 5B. The exception is the results for 50 to 59 year olds in Table 5A, where the wage effects are in the opposite direction of the LFP effects.

The striking finding here, in our view, is that when we break up the cohorts to which we compare the size of the older cohort, we get far less contradictory evidence of the effects of a larger, older cohort. (Recall that, in Tables 2 and 4, we found that the LFP effects of large older cohorts point to a positive demand shift toward older workers when the older cohort is larger, while the wage effects point to a negative relative supply effect.) And for the 60-to 69-year-old cohort, in particular, the contradictory evidence evaporates completely.

Table 6 provides an overview of this evidence, reporting the results only for men and women combined (which are similar to the separate estimates by sex). The last two columns contrast the key results for the two older cohorts. For the Table 2 and 4 IV results - which simply estimate the effects of the relative size of the older cohorts — the LFP and wage evidence is always contradictory with regard to the relative cohort size hypothesis (lightly shaded boxes). But the Table 5A and 5B IV results — which estimate separate effects of the sizes of the older cohorts relative to the two younger cohorts - provide much less contradictory evidence (darkly shaded boxes).

How do we interpret the findings? The evidence of large negative effects on both LFP and wages for older workers ages 60 to 69 , when their cohort is large relative to the youngest cohort, indicates that the oldest and the youngest workers are not very substitutable. Rather a large older cohort of 60 to 69 year olds relative to 16 to 24 year olds creates traditional, supply-side cohort crowding effects for older workers. This suggest that the effects are not driven by whether older workers taking post-retirement jobs move into jobs otherwise held by young people.

The results for the size of the 60- to 69-year-old cohort relative to the prime-aged cohort (25 to 49), however, are more consistent with a relative demand shift. There is a strong positive effect on LFP, suggesting that when the older cohort is large relative to the prime-aged cohort, 
demand for older workers is strong. When prime-aged workers are relatively scarce, firms may try to retain older workers. It is true that we do not find a corresponding positive wage effect for the older cohort; the estimates are not significantly different from zero, although they are negative, rather than positive. While we cannot explain negative estimates via the demand side, if older workers' labor supply on the extensive margin is quite elastic, that could militate against finding a positive wage effect. And it is possible that the absence of wage effects or even negative effects, despite a positive demand shift, could arise from older workers entering into different kinds of employment relationships with their prior employers or new employers that are more flexible and pay less, ${ }^{26}$ or from negative selection on wages of who remains employed at older ages.

For 50 to 59 year olds, the evidence for the effects of cohort size relative to the size of the youngest cohort (ages 16 to 24) is also no longer contradictory, as five of the six estimates are negative, and the sixth is very close to zero. The negative estimates are consistent with the conventional relative cohort size effect, like we found for 60 to 69 year olds relative to 16 to 24 year olds (although the evidence was much stronger in this case). Only for the estimates for 50 to 59 year olds relative to 25 to 49 year olds does a contradiction remain, as we find positive estimates of the relative size of the older cohort on LFP, but negative and significant estimates on wages. Note, though, that the positive effects on LFP are the same as for 60 to 69 year- olds, although, again, the magnitudes are smaller.

Thus, the disaggregation of the younger cohorts to a large extent resolves the contradictory evidence we found when lumping all "non-old" cohorts together. We find strong evidence, when compared to the size of younger cohorts, of traditional cohort crowding for workers ages 60 to

\footnotetext{
${ }^{26}$ For example, Johnson et al. (2009, Table 1) reports that, among workers age 51 to 55 in 1992, as of 200614.2 percent remained at the same employer, 15.7 percent changed employer and stayed in the same occupation, and 26.9 percent changed employer and occupation. (The remainder were not employed.) And average wages are considerably lower on the new job (Table 17), which is typically less physically demanding, especially for those for those who changed occupations (Table 2).
} 
69. And when compared to the size of prime-aged cohorts, we found more evidence that large relative size of the oldest cohort is associated with a shift in demand toward older workers, although we cannot fully explain both the LFP and wage effects for the effects of the size of older relative to prime-aged cohorts in a simple demand and supply framework.

\section{What do workers in older cohorts do when their younger cohorts are smaller?}

The evidence from Tables 5A and 5B suggests that when the older cohorts of 50 to 59 or 60 to 69 year olds are large relative to the 25 - to 49 -year-old cohort, LFP of the older cohorts is higher. This is consistent with an increase in demand for members of the older cohorts. Yet wages do not rise, which we speculated could be in part because the older workers induced to participate in the labor force when the younger prime-age cohort is smaller are entering into different kinds of employment relationships, possibly with lower pay. In this subsection, we present some evidence on this conjecture.

Table 7 reports IV estimates of specifications similar to those in Tables 5A and 5B, with the difference that we estimate models for the share of the labor force working part-time, or selfemployed. If the LFP response among the older cohorts occurs via different kinds of employment relationships, then we might expect the shares of part-time or self-employment to increase. Moreover, a self-employment response of this nature would be more likely to be for an unincorporated self-employed business, such as someone taking on a consulting role for a former employer. Hence, we also report specifications for the shares of the labor force in selfemployment broken down by incorporation status. Aside from that, the approach is exactly as in Tables 5A and 5B, with the same first-stage, etc.

The estimates indicate that the margin of response for 50 to 59 year olds to a smaller relative 25- to 49-year-old cohort is an increase in the share of the labor force working as self- 
employed. This effect is evident only for the unincorporated self-employed, as hypothesized. ${ }^{27}$ For 60 to 69 year olds, Table 7 indicates that the margin of response to a smaller 25 - to 49 -yearold cohort is an increase in the share of the labor force working part-time. Together, this evidence is consistent with older cohorts participating in the labor force at a higher rate, when their cohorts are large relative to 25 to 49 year olds, in employment relationships that differ from common full-time, wage and salary arrangements. That is what we might expect given that the increase in LFP when old cohorts are relatively large come from those less attached to the labor force (and hence not participating when the relative size of older cohorts is not large).

Do these participation responses of older cohorts also explain the absence of positive wage effects (or even negative wage effects for 50 to 59 year olds), in response to large cohorts of older workers relative to 25 to 49 year-olds? To explore this, Table 8 simply reports regressions of our log average hourly wage measure on the shares of older workers in these alternative work arrangements. The evidence suggests that part-time work is associated with lower wages, although self-employment is not. Thus, these wage results provide a partial explanation for why the increase in LFP of older cohorts, when they are large relative to the 25- to 49-year-old cohort, is not accompanied by higher wages — as we would expect from a pure labor demand story. The explanation works for 60 to 69 year olds - for whom the response occurs in parttime work - but not 50 to 59 year olds.

\section{Conclusions}

Our paper is motivated by the question of the effect of "cohort crowding" for older workers. When there is a relatively large cohort of older individuals, do we find that wages and labor force participation (LFP) are lower, because of the relative supply effect? Such evidence

\footnotetext{
${ }^{27}$ There is also a smaller positive effect, significant at the 10-percent level, in response to a smaller 16- to 24-year-old cohort, although Table 5A did not point to an increase in LFP for 50 to 59 year olds when their cohort is large relative to 16 to 24 year olds.
} 
would be consistent with other research on younger workers. Or do we find different effects, perhaps because the age composition of the population affects the age composition of consumption and, hence, labor demand, or because a large relative cohort of older workers implies a small relative cohort of younger workers, which can itself affect demand for older workers?

We explore these effects of relative cohort size, taking account of the potential endogeneity of population structure owing to both work-related and retirement-related migration. We use as instrumental variables relative cohort size measures predicted by historical data on births in each state, by year. In general, we find evidence consistent with the kinds of biases we would expect from these two types of migration, and hence we emphasize the instrumental variables results.

When we study the effects of a large relative older cohort (ages 50 to 59 or 60 to 69) relative to the working-age population as a whole, we find somewhat contradictory evidence. For LFP, we find evidence that is inconsistent with the relative supply or cohort crowding hypothesis, and which instead suggests an increase in demand for older workers when the older cohort is relatively large (with higher LFP). But we find negative wage effects, consistent with the relative supply hypothesis.

However, when we look at the size of the older cohorts relative to a young cohort (ages 16 to 24) and a cohort spanning the prime/middle range of ages (25 to 49), we find a more coherent set of results. When the older cohort is large relative to the younger cohort, the evidence is much more consistent with the relative supply hypothesis, with a larger relative older cohort reducing LFP and wages. But when the older cohorts are large relative to the cohort of 25 to 49 year olds, LFP of older workers is higher, and it is less clear that wages are affected.

These results for the size of older cohorts relative to prime-aged cohorts are more consistent with a relative demand shift. When prime-aged workers are scarce relative to older workers, firms may try to retain or hire older workers. Older workers' extensive margin labor 
supply elasticity may be quite high. Moreover, older workers often enter into different jobs or employment relationships with more flexible, lower-paying work. There is some evidence from data on part-time work and self-employment that the increase in older workers' LFP when their cohort is large relative to the 25 - to 49 -year-old cohort comes via self-employment or part-time work. Moreover, for 60 to 69 year olds this may help explain why average wages do not rise despite the increase in LFP. For 50 to 59 year olds, in contrast, there remains more of a contradiction between higher LFP but lower wages when their cohort is large relative to 25 to 49 year olds.

Together, the results suggest that cohort size may have important implications for the LFP (and wages) of older workers. However, our evidence suggests that we need a more nuanced view than simply whether the older cohort is large relative to the population: The cohort they are large relative to matters. Our evidence also suggests the value of additional work to understand the behavior underlying our findings, both to better understand the labor market decisions of older workers, and to assess the validity of the interpretation of the results we find in this paper. 


\section{References}

Berger, Mark C. 1984. "Cohort Size and the Earnings Growth of Young Workers." Industrial and Labor Relations Review 37(4): 582-91.

Burtless, Gary. 1986. "Social Security, Unanticipated Benefit Increases, and the Timing of Retirement." Review of Economic Studies 53(5): 781-805.

Centers for Disease Control and Prevention. n.d. (a). National Vital Statistics Reports. https://www.cdc.gov/nchs/products/nvsr.htm (viewed April 21, 2017).

Centers for Disease Control and Prevention. n.d. (b). Vital Statistics of the United States." https://www.cdc.gov/nchs/products/vsus.htm (viewed April 21, 2017).

Cohen, Jeremye D. 2006. "The Aging Nurse Workforce: How to Retain Experienced Nurses." Journal of Healthcare Management 51(4): 233-45.

Evers, Michiel, Ruud de Mooij, and Daniel van Vuuren. 2008. "The Wage Elasticity of Labor Supply: A Synthesis of Empirical Estimates." De Economist 156(1): 25-43.

Flood, Sarah, Miriam King, Steven Ruggles, and J. Robert Warren. 2017. Integrated Public Use Microdata Series, Current Population Survey: Version 5.0 [dataset]. Minneapolis, MN: University of Minnesota. https://doi.org/10.18128/D030.V5.0

French, Eric, and John Jones. 2012. "Public Pensions and Labor Supply Over the Life Cycle." International Tax and Public Finance 19(2): 268-87.

Friedberg, Leora. 2000. "The Labor Supply Effects of the Social Security Earnings Test." Review of Economics and Statistics 82(1): 429-450.

Gruber, Jonathan, and David A. Wise. 2007. Social Security Programs and Retirement around the World. Chicago: University of Chicago Press.

Gustman, Alan L., and Thomas L. Steinmeier. 2005. "The Social Security Early Entitlement Age in a Structural Model of Retirement and Wealth." Journal of Public Economics 89(2-3): 441-63.

Heckman, James J., Lance J. Lochner, and Petra E. Todd. 2006. “Earnings Functions, Rates of Return and Treatment Effects: The Mincer Equation and Beyond." In Handbook of the Economics of Education, Volume 1, edited by Erik Hanushek and Finis Welch, 307-458. Amsterdam: Elsevier. 
Johnson, Richard W., Janette Kawachi, and Eric K. Lewis. 2009. “Older Workers on the Move: Recareering in Later Life.” AARP Public Policy Institute. Washington, DC: AARP.

Korenman, Sanders and David Neumark. 2000. "Cohort Crowding and Youth Labor Markets: A Cross-National Analysis." In Youth Employment and Joblessness in Advanced Countries, edited by David Blanchflower and Richard Freeman, 57-106. Chicago: University of Chicago Press.

Macunovich, Diane J. 1999. “The Fortunes of One's Birth: Relative Cohort Size and the Youth Labor Market in the United States.” Journal of Population Economics 12(2): 215-272.

Maestas, Nicole. 2010. "Back to Work: Expectations and Realizations of Work after Retirement." Journal of Human Resources 45 (Summer): 718-48.

Morin, Louis-Philippe. 2015. "Cohort Size and Youth Earnings: Evidence from a QuasiExperiment." Labour Economics 32: 99-111.

Mueller, Andreas I., Jesse Rothstein, and Till M. von Wachter. 2016. "Unemployment Insurance and Disability Insurance in the Great Recession." Journal of Labor Economics 34(S1): S445S475.

Munnell, Alicia H. 2015. "The Average Retirement Age - An Update." Center for Retirement Research at Boston College, http://crr.bc.edu/wp-content/uploads/2015/03/IB_15-4.pdf (viewed March 15, 2018).

National Center for Health Statistics. 1976-1977. Advance Report Final Natality Statistics, (various years, 1974-1975. Rockville: National Center for Health Statistics.

National Center for Health Statistics. 1978-1980. Advance Report Final Natality Statistics, (various years, 1976-1978. Hyattsville: National Center for Health Statistics.

National Center for Health Statistics. 1982-1996. Advance Report of Final Natality Statistics (various years, 1980-1994). Hyattsville: National Center for Health Statistics.

National Center for Health Statistics. 1934. Birth, Stillbirth, and Infant Mortality Statistics for the Birth Registration Area of the United States 1931. Washington: U.S. Government Printing Office. 
National Center for Health Statistics. 1934-1938. Birth, Stillbirth, and Infant Mortality Statistics for the Continental United States, the Territory of Hawaii, the Virgin Islands 1933 (various years, 1932-1936) Washington: U.S. Government Printing Office.

National Center for Health Statistics. 1999-2017. Births: Final Data for (various years, 1997-2015). Hyattsville: National Center for Health Statistics.

National Center for Health Statistics. 1997-1998. Report of Final Natality Statistics, (various years, 1995-1996). Hyattsville: National Center for Health Statistics.

National Center for Health Statistics. 1974-1975. Summary Report Final Natality Statistics, (various years, 1970-1974)

National Center for Health Statistics. 1939-2005. Vital Statistics of the United States (various years, 1937-2003) Washington: U.S. Government Printing Office.

National Center for Health Statistics. 1984. Vital Statistics of the United States 1979 Volume 1: Natality. Hyattsville: National Center for Health Statistics.

National Office of Vital Statistics. 1968. Vital Statistics Rates in the United States 1900-1940. Report prepared by Linder, Forrest E., and Robert D. Grove. Washington: United States Government Printing Office.

National Center for Health Statistics. 1947. Vital Statistics Rates in the United States 1940-1960. Report prepared by Grove, Robert D., and Alice M. Hetzel. Washington: United States Government Printing Office.

Neumark, David, and Patrick Button. 2014. "Did Age Discrimination Protections Help Older Workers Weather the Great Recession?” Journal of Policy Analysis and Management 33(3): 566-601.

Neumark, David, and Joanne Song. 2013. "Do Stronger Age Discrimination Laws Make Social Security Reforms More Effective?” Journal of Public Economics 108: 1-16.

Reinhardt, Uwe. 2003. "Does the Aging of the Population Really Drive the Demand for Health Care?" Health Affairs 22(6): 27-39.

Richardson, H.W. 1995. "Economies and Diseconomies of Agglomeration.” In Urban Agglomeration and Economic Growth, edited by Herbert Giersch, 122-55. Berlin: Springer. 
Stapleton, David C., and Douglas J. Young. 1988. "Educational Attainment and Cohort Size." Journal of Labor Economics 6(3): 330-61.

Stock, James H., and Motohiro Yogo. 2005. "Testing for Weak Instruments in Linear IV Regression." In Identification and Inference of Econometric Models: Essays in Honor of Thomas Rothenberg, edited by Donald W. Andrews and James H. Stock, 80-108. Cambridge: Cambridge University Press.

Welch, Finis. 1979. “Effects of Cohort Size on Earnings: The Baby Boom Babies' Financial Bust.” Journal of Political Economy 87(5): S65-S97. 


\section{Figure 1: Labor Force Participation Rates by Age Group, Over Time}

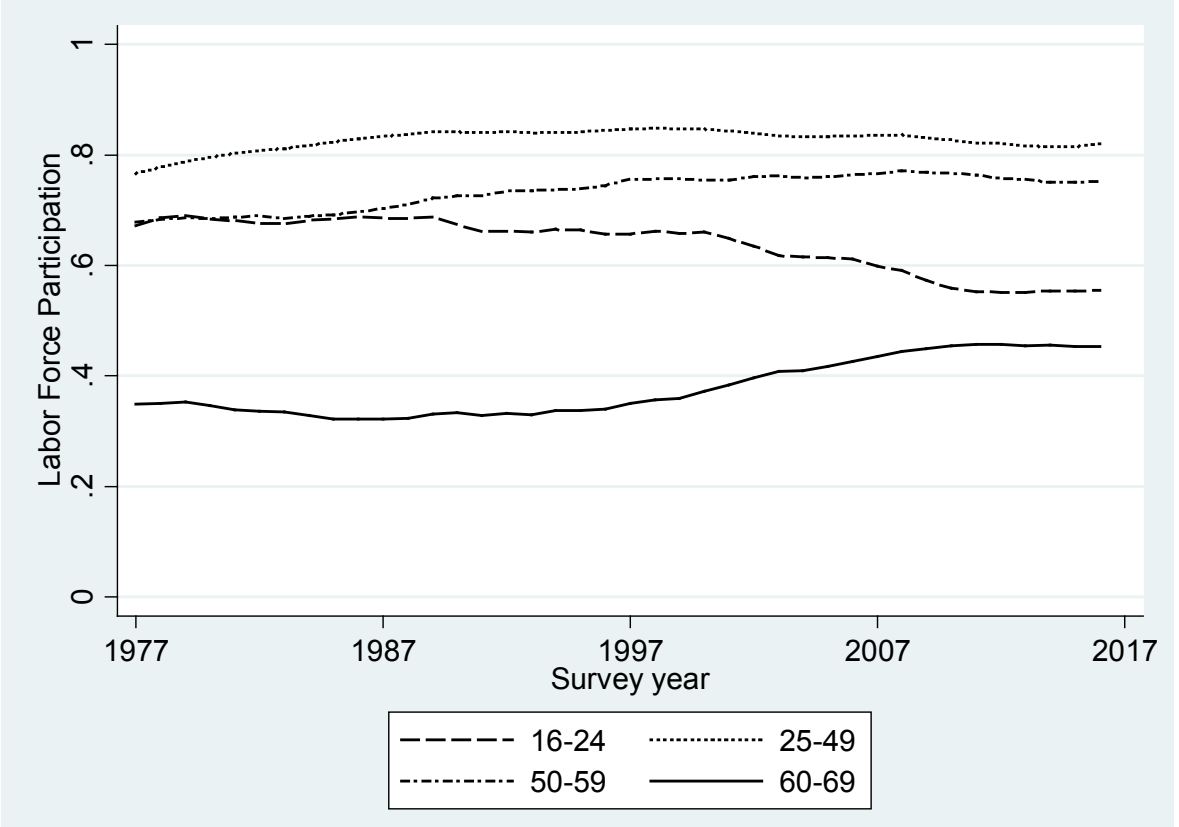

Source: Census Population Survey (CPS) 1977-2016. A state panel is first constructed from CPS monthly basic files by aggregating labor force participation for each state, year, and age group. Figure 1 is created from a weighted averages of all states' labor force participation rates, weighted by state population. 


\section{Figure 2: Population Shares of Age Groups, Over Time}

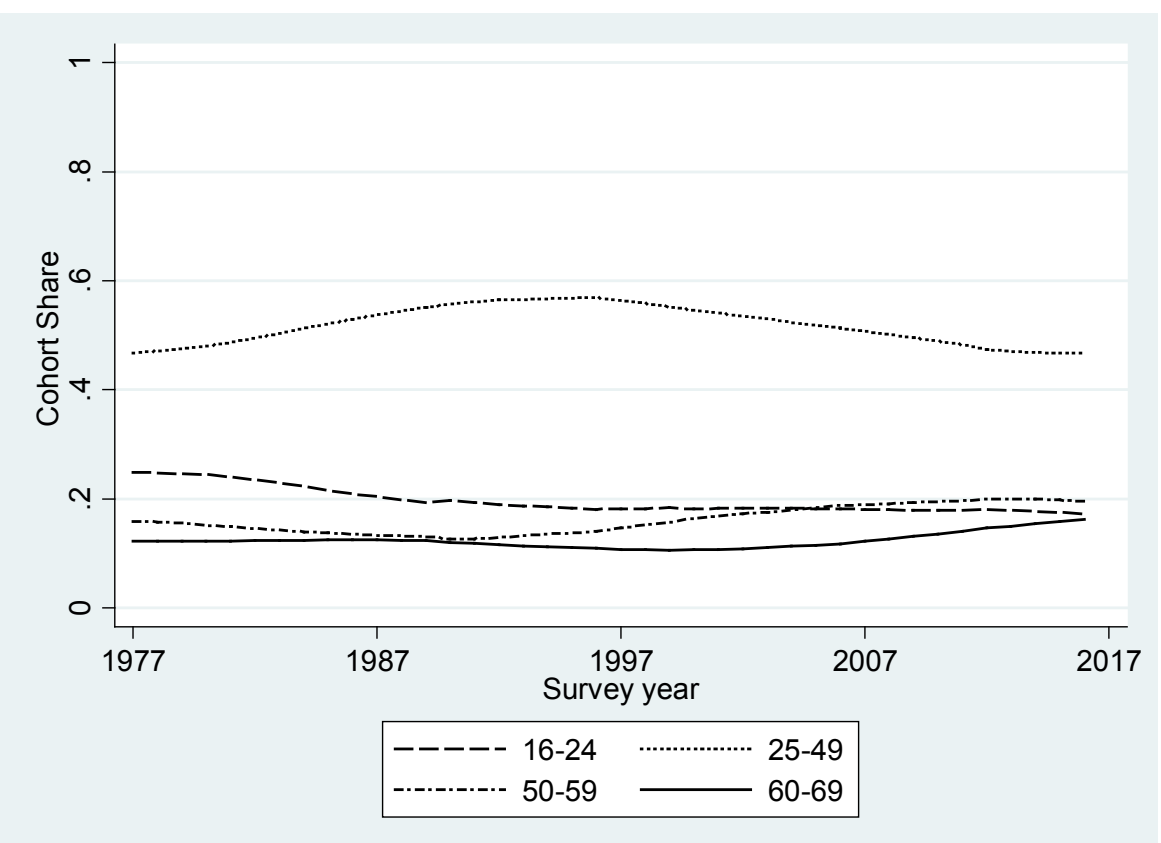

Source: Census Population Survey (CPS) 1977-2016. Cohort share is constructed from the CPS monthly basic files by dividing the sum of the CPS survey weights for each age group in each state and year by the total sum of the survey weights for ages 16-69 in each state and year. Figure 2 is constructed from weighted averages of all the states' cohort shares, weighted by state population. 
Figure 3: Labor Force Participation Rates and Cohort Shares by Age Group, Over Time

A. 16-24 year-olds

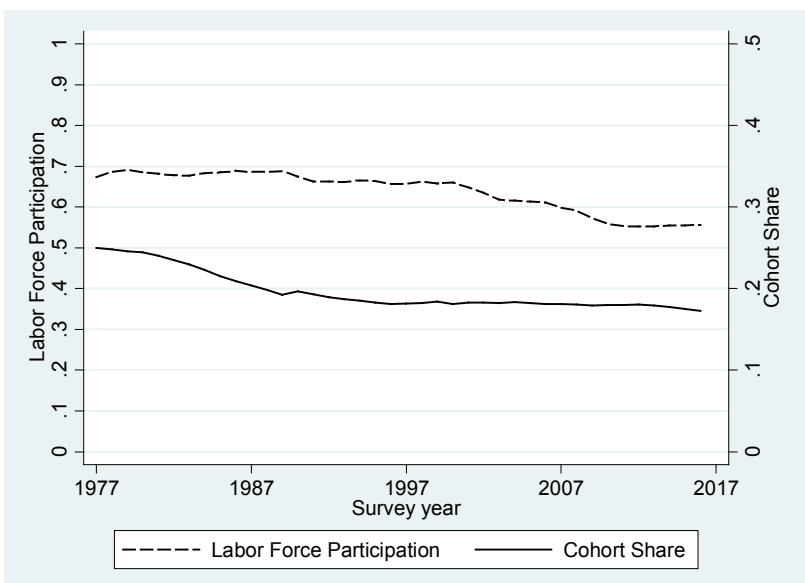

C. 50-59 year-olds

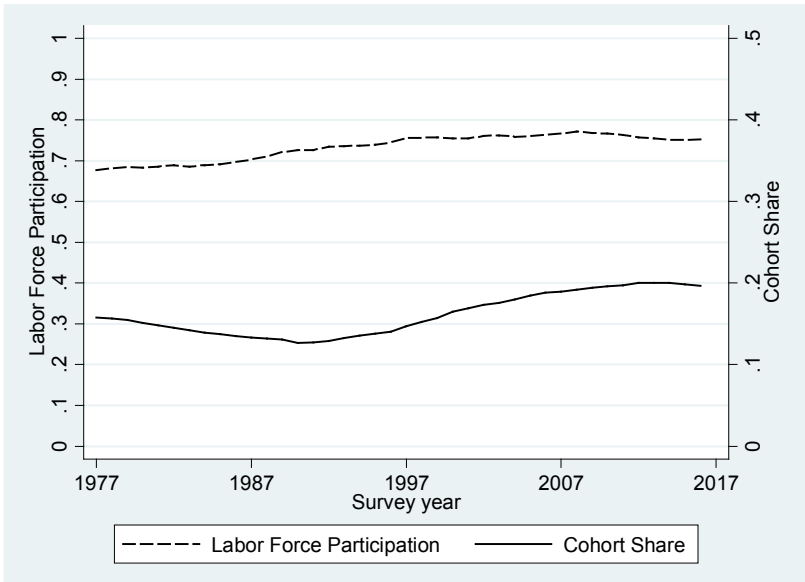

B. 25-49 year-olds

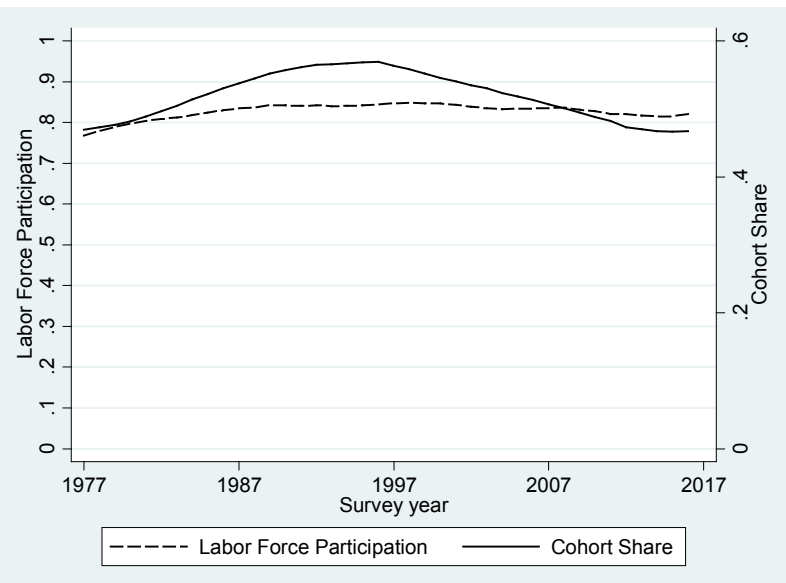

D. 60-69 year-olds

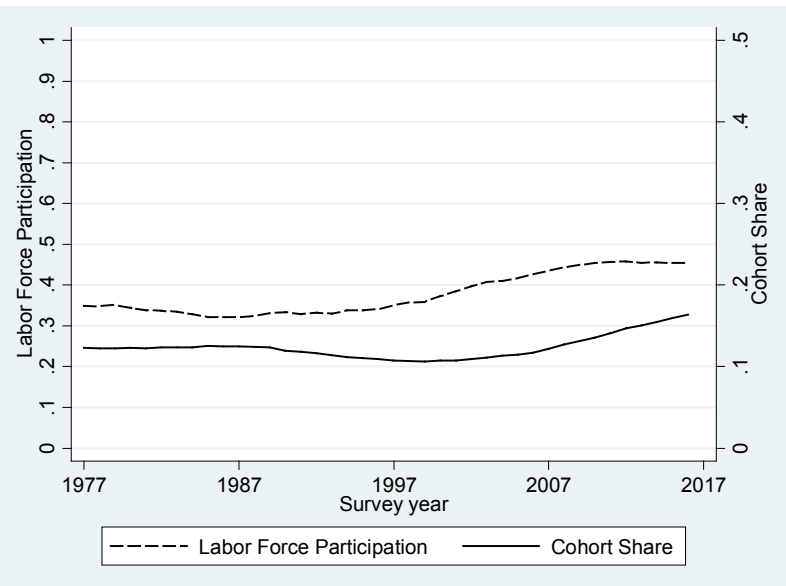

Source: Data source and series construction are explained in notes to Figures 1 and 2. Pearson correlation coefficients for $16-24,25-59$, and $60-69$ year-olds are $0.640,0.784,0.628$, and 0.595 respectively. 
Figure 4: Wages and Cohort Shares by Age Group, Over Time

A. 16-24 year-olds

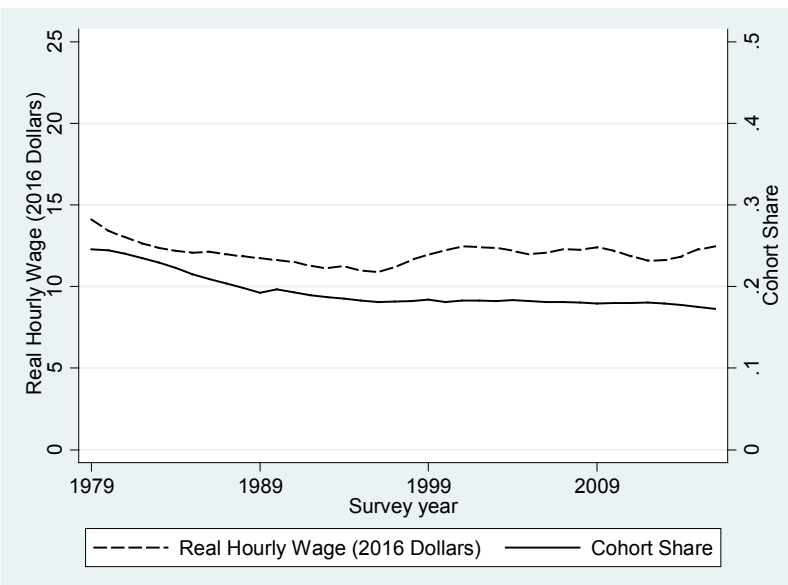

C. 50-59 year-olds

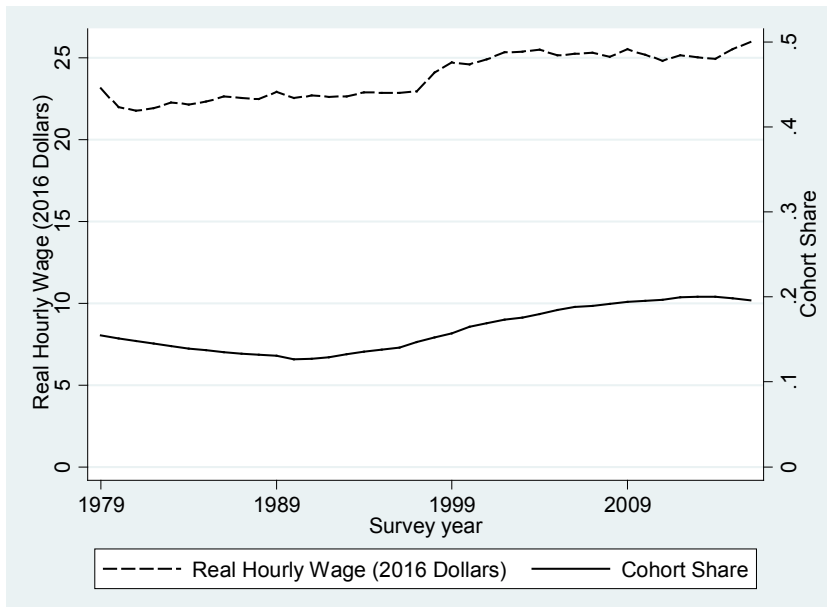

B. 25-49 year-olds

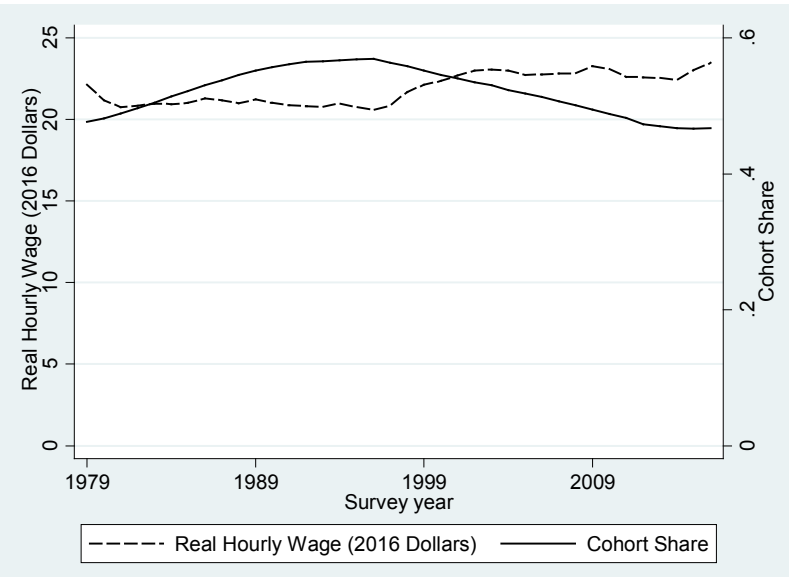

D. 60-69 year-olds

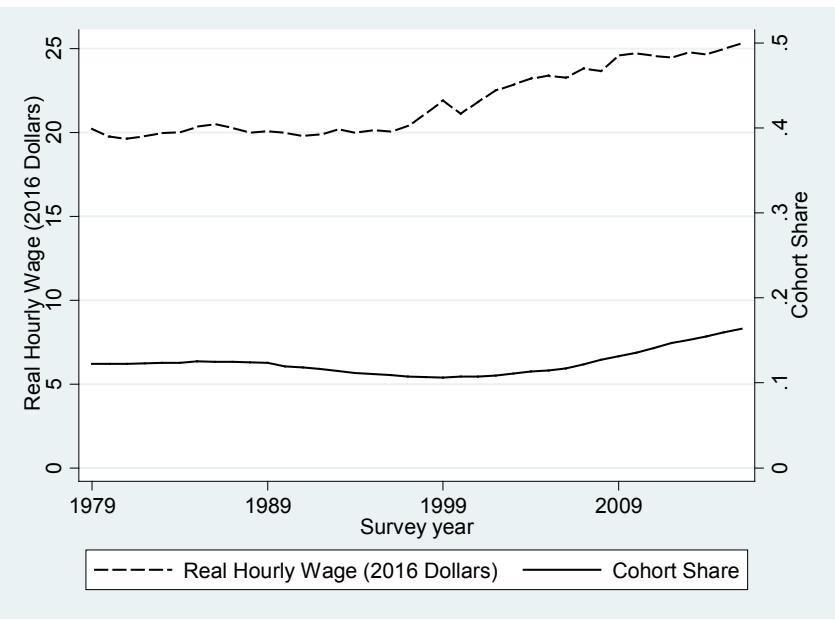

Source: Census Population Survey (CPS) monthly basic files and Outgoing Rotation Group (ORG) files (1979-2016). Hourly wages are used if available or constructed from average weekly earnings divided by usual hours worked if not available. Individuals with wages below half a state's minimum wage or above \$200/hour in 2016 dollars are dropped. A state panel on wages is first constructed from the ORG files by aggregated hourly wages for each state and year for each age group. The cohort share variable is constructed as described in notes to Figure 2. Figure 4 is constructed from weighted averages of all the states' hourly wages and cohort shares, weighted by state population. Pearson correlation coefficients for 16-24, 25-59, and 60-69 year-olds are $0.599,-0.547,0.894$, and 0.627 respectively. 


\section{Figure 5: Labor Force Participation Rates and Cohort Shares by Age Group, 1977-2016 Changes by State}

A. 16-24 year-olds

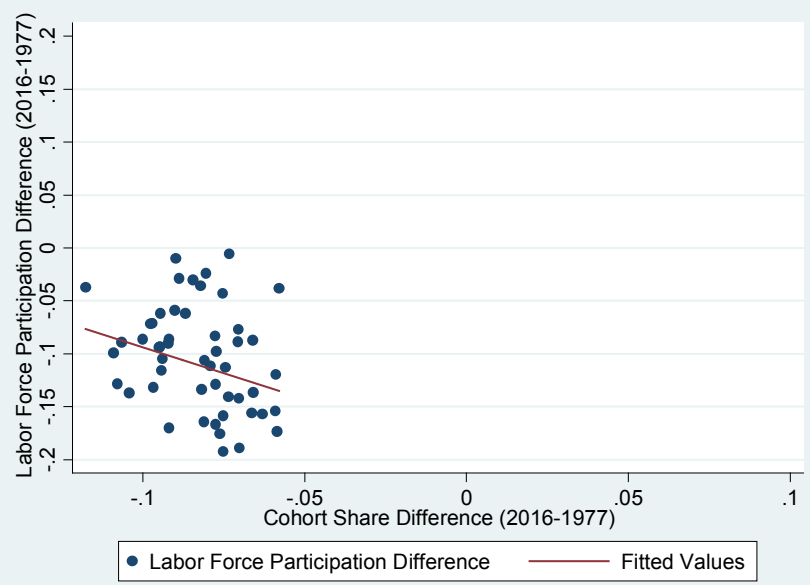

C. 50-59 year-olds

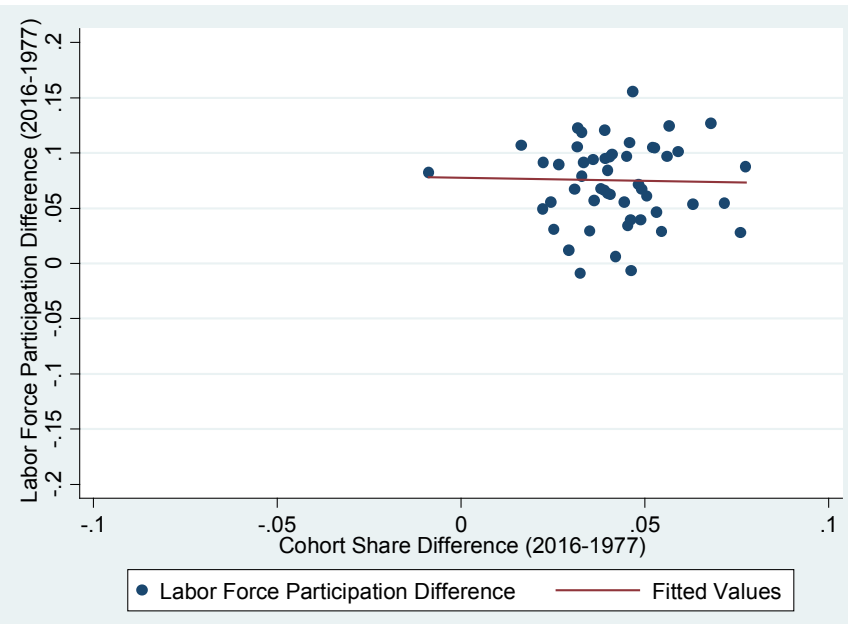

B. 25-49 year-olds

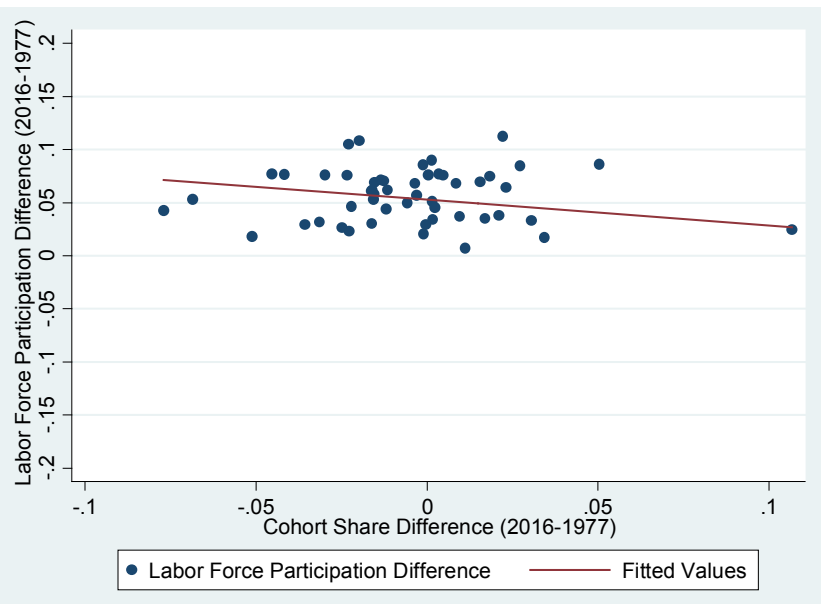

D. 60-69 year-olds

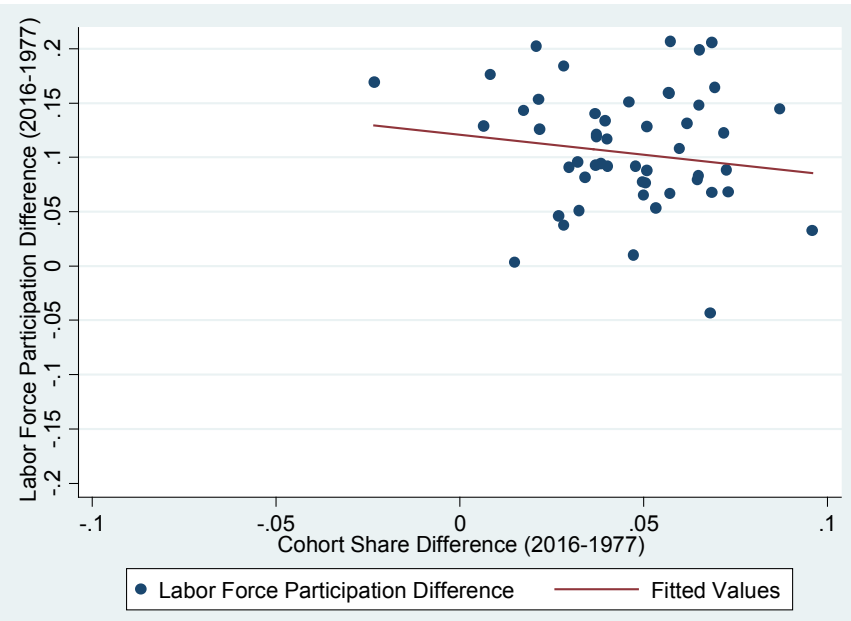

Source: Data source and series construction are explained in notes to Figures 1 and 2. These figures plot the 1977 to 2016 changes, by state. Fitted values are from regressing the changes in LFP on changes in cohort share differences, weighted by state population through 1977-2016. Regression coefficients and standard errors (given in parentheses) for the 16-24 year-old, 25-49 year-old, 50-59, and 60-69 year-old cohorts are $-0.979(0.490),-0.244(0.198),-0.051(0.368)$, and $-0.366(0.346)$ respectively. 
Figure 6: Wages and Cohort Shares by Age Group, 1979-2016 Changes by State

A. 16-24 year-olds

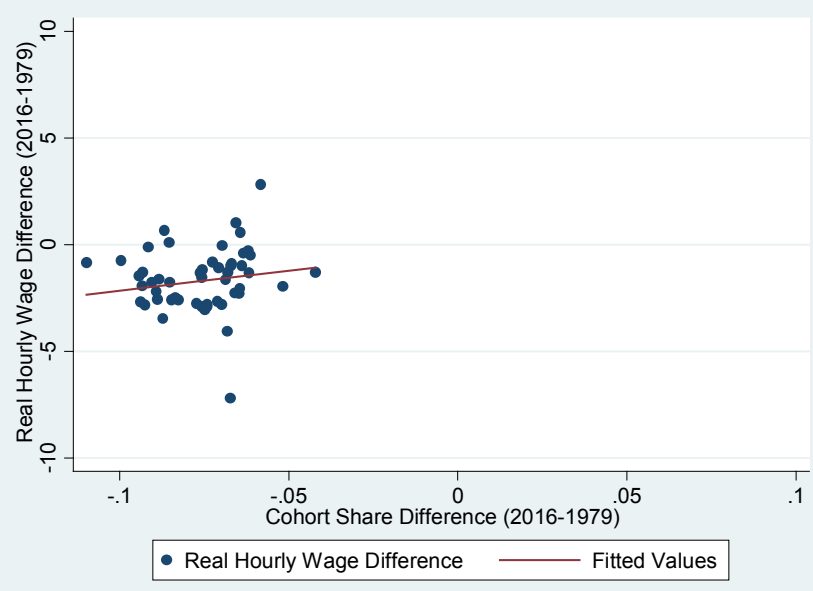

C. 50-59 year-olds

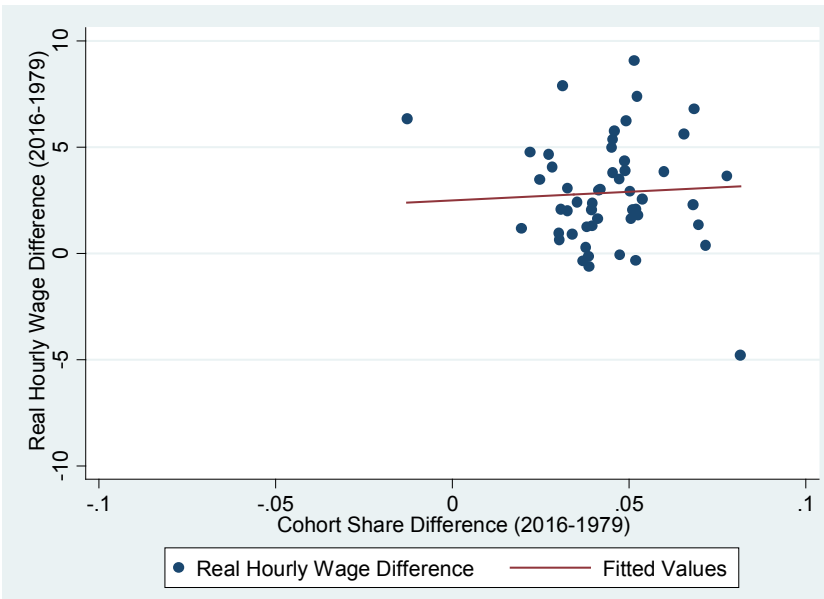

B. 25-49 year-olds

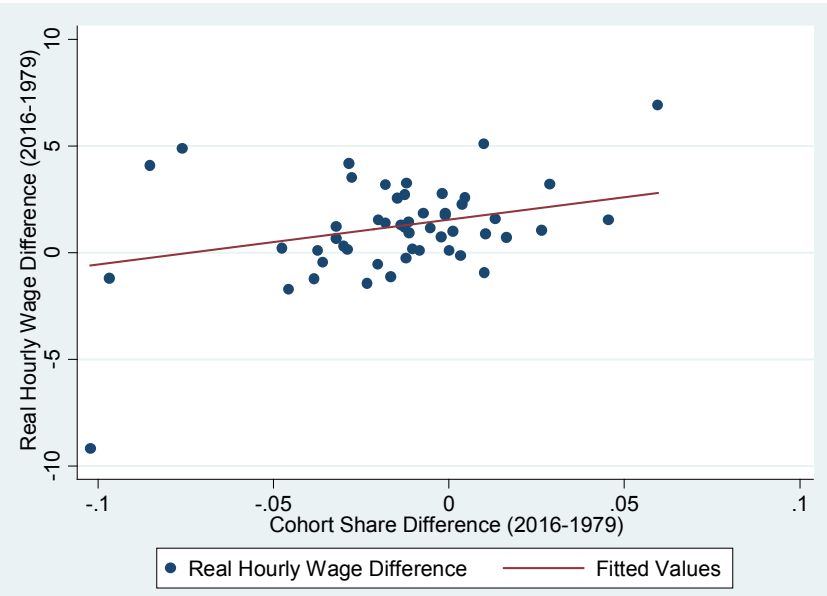

D. 60-69 year-olds

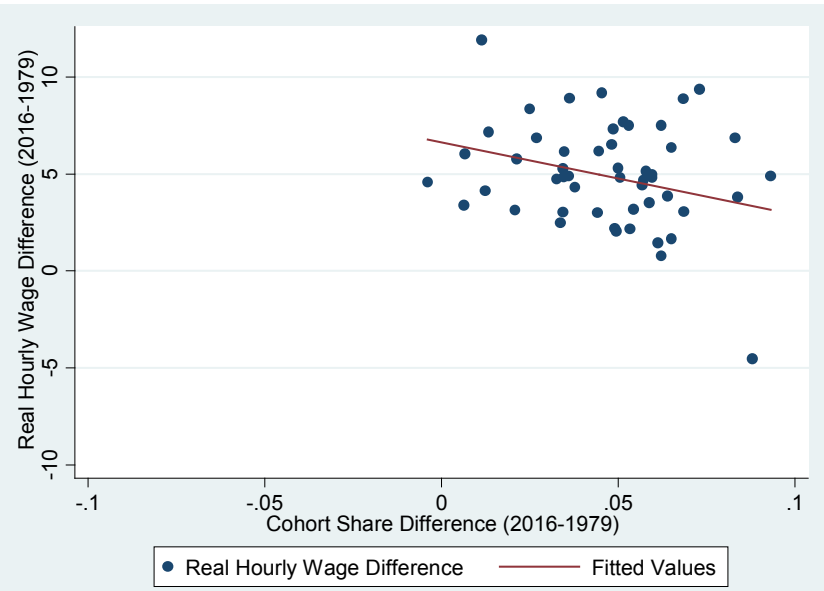

Source: Data source and series construction are explained in notes to Figures 2, 4, and 5. Regression coefficients and standard errors (given in parentheses) for the 16-24 year-old, 25-49 year-old, 50-59 year-old, and 60-69 year-old cohorts are 18.83 (11.65), 42.161 (2.91), and -37.08 (17.46) respectively. (Note that the implied effect of a one percentage point change in the cohort share is $1 / 100^{\text {th }}$ of these coefficients.) 
Table 1: OLS Regressions of Log Labor Force Participation Rate on Log Cohort Share, 1977-2016

\begin{tabular}{|c|c|c|c|c|c|c|c|c|c|c|c|c|}
\hline Sex & \multicolumn{4}{|c|}{ Both sexes } & \multicolumn{4}{|c|}{ Men } & \multicolumn{4}{|c|}{ Women } \\
\hline Age & $16-24$ & $25-49$ & $50-59$ & $60-69$ & $16-24$ & $25-49$ & $50-59$ & $60-69$ & $16-24$ & $25-49$ & $50-59$ & $60-69$ \\
\hline $\begin{array}{l}\text { In(Cohort Size/Pop } \\
16-69)\end{array}$ & $\begin{array}{l}0.097^{* * \pi} \\
{[0.025]}\end{array}$ & $\begin{array}{l}0.039^{* *} \\
{[0.019]}\end{array}$ & $\begin{array}{l}0.049^{* * \pi} \\
{[0.015]}\end{array}$ & $\begin{array}{l}-0.134^{* *} \\
{[0.034]}\end{array}$ & $\begin{array}{l}0.032 \\
{[0.025]}\end{array}$ & $\begin{array}{l}-0.002 \\
{[0.011]}\end{array}$ & $\begin{array}{l}0.031^{\text {** }} \\
{[0.012]}\end{array}$ & $\begin{array}{l}- \\
0.076^{* *} \\
{[0.032]}\end{array}$ & $\begin{array}{l}0.101^{\text {** }} \\
{[0.026]}\end{array}$ & $\begin{array}{l}0.039 \\
{[0.036]}\end{array}$ & $\begin{array}{l}0.064^{\text {**x }} \\
{[0.024]}\end{array}$ & $\begin{array}{l}-0.105^{*} \\
{[0.045]}\end{array}$ \\
\hline $\begin{array}{l}\text { Mean LFP } \\
\mathbf{R}^{2} \\
\text { Incremental } \mathbf{R}^{2}\end{array}$ & $\begin{array}{l}0.64 \\
0.92 \\
0.029\end{array}$ & $\begin{array}{l}0.83 \\
0.91 \\
0.032\end{array}$ & $\begin{array}{l}0.73 \\
0.90 \\
0.007\end{array}$ & $\begin{array}{l}0.38 \\
0.89 \\
0.011\end{array}$ & $\begin{array}{l}0.67 \\
0.92 \\
0.014\end{array}$ & $\begin{array}{l}0.93 \\
0.91 \\
0.014\end{array}$ & $\begin{array}{l}0.83 \\
0.81 \\
0.023\end{array}$ & $\begin{array}{l}0.45 \\
0.80 \\
0.012\end{array}$ & $\begin{array}{l}0.61 \\
0.89 \\
0.050\end{array}$ & $\begin{array}{l}0.73 \\
0.92 \\
0.036\end{array}$ & $\begin{array}{l}0.64 \\
0.93 \\
0.005\end{array}$ & $\begin{array}{l}0.31 \\
0.88 \\
0.005\end{array}$ \\
\hline
\end{tabular}

Notes: Data sources are described in notes to Figures 1 and 2. The table reports estimates of equation (1). All specifications include fixed state and year effects, controls for the unemployment rate, state GDP growth, a constant, and the shares married, Hispanic, non-Hispanic black, with a bachelor's degree or more, high school dropouts, and urban. The "Both" columns also include the share female. Regression weighted by average state population through the sample period. Uses Newey-West standard errors to account for heteroskedasticity and autocorrelation. Estimates are weighted by average state population through the sample period. ${ }^{*},{ }^{* *}$, and ${ }^{* * *}$ denotes $0.1,0.05$, and 0.01 significance. Incremental $\mathrm{R}^{2}$ refers to addition to $\mathrm{R}^{2}$ beyond fixed state and year effects. $\mathrm{N}=2,040$. 
Table 2: OLS and IV Regressions of Log Labor Force Participation Rate on Log Cohort Share, 1984-2016, Both Sexes

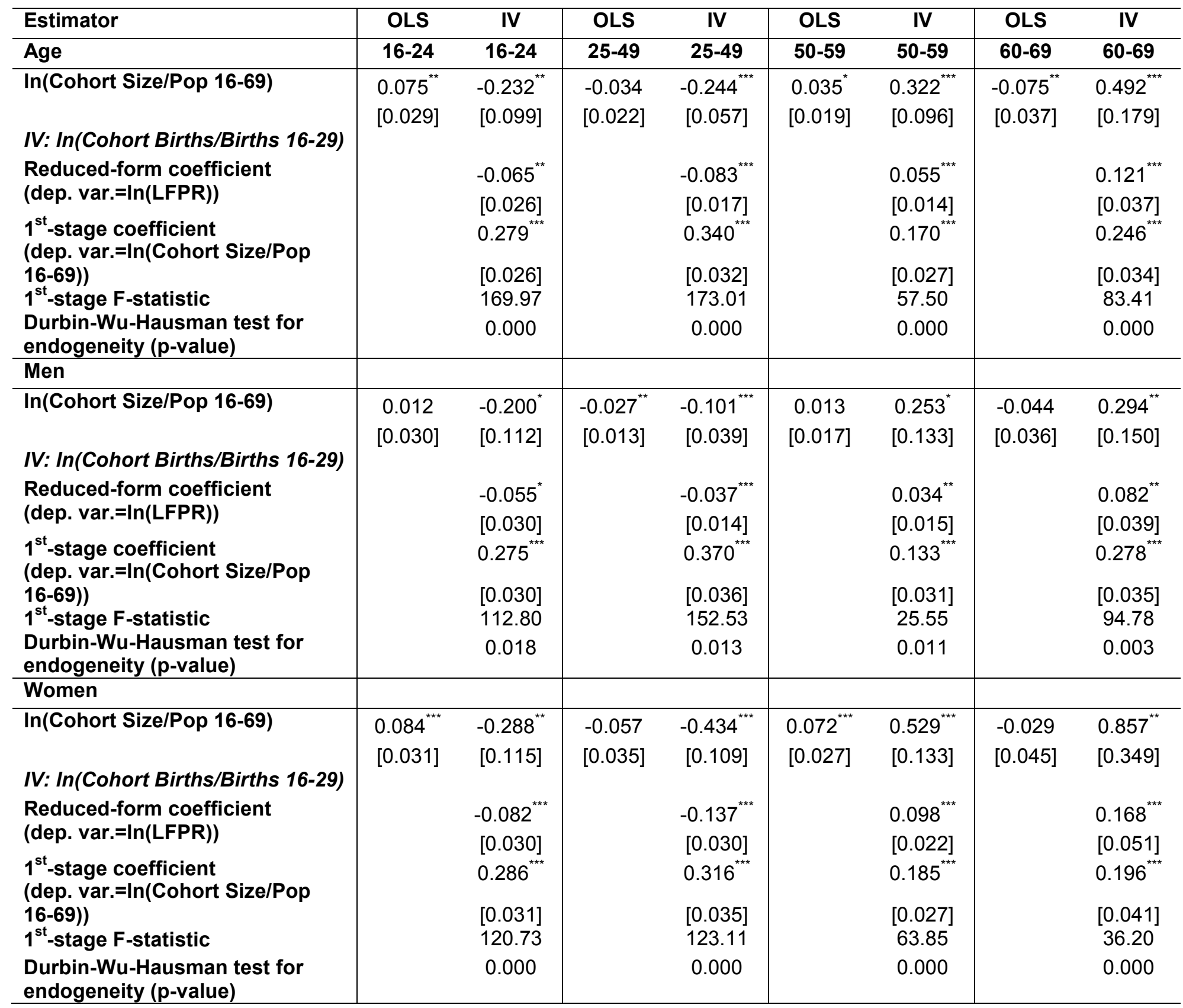

Notes: Data source is described in notes to Figures 1 and 2, and specification details are described in notes to Table 1A. The table reports estimates of equation (1). Regression weighted by average state population through the sample period. Uses Newey-West standard errors to account for heteroskedasticity and autocorrelation. ${ }^{*},{ }^{* *}$, and ${ }^{* * *}$ denotes $0.1,0.05$, and 0.01 significance. The instrumental variable used for the cohort share is the total number of births within an age-cohort by state and year divided by the total number of births for 16-69 year-olds by state and year. We exclude certain years and states with missing birth data for the cohorts, as only a handful of states started reporting births in 1915 . $\mathrm{N}=1,326$. 
Table 3: OLS Regressions of Log Average Hourly Wage on Log Cohort Share, 1979-2016

\begin{tabular}{|c|c|c|c|c|c|c|c|c|c|c|c|c|}
\hline \multirow[b]{2}{*}{ Age } & \multicolumn{4}{|c|}{ Both sexes } & \multicolumn{4}{|c|}{ Men } & \multicolumn{4}{|c|}{ Women } \\
\hline & $16-24$ & $25-49$ & $50-59$ & $60-69$ & $16-24$ & $25-49$ & $50-59$ & $60-69$ & $16-24$ & $25-49$ & $50-59$ & $60-69$ \\
\hline $\begin{array}{l}\text { In(Cohort Size/Pop 16- } \\
69)\end{array}$ & $\begin{array}{l}-0.058^{* *} \\
{[0.028]}\end{array}$ & $\begin{array}{l}0.216^{* * *} \\
{[0.043]}\end{array}$ & $\begin{array}{c}- \\
0.057^{* *} \\
{[0.026]}\end{array}$ & $\begin{array}{c}-0.026 \\
{[0.034} \\
]\end{array}$ & $\begin{array}{l}-0.055^{* *} \\
{[0.028]}\end{array}$ & $\begin{array}{l}0.172^{* *} \\
{[0.043]}\end{array}$ & $\begin{array}{c}- \\
0.039^{*} \\
{[0.023} \\
]\end{array}$ & $\begin{array}{c}{[0.039} \\
\quad]\end{array}$ & $\begin{array}{l}-0.008 \\
{[0.026]}\end{array}$ & $\begin{array}{l}0.200^{* * *} \\
{[0.039]}\end{array}$ & $\begin{array}{c}- \\
0.048^{*} \\
{[0.026} \\
]\end{array}$ & $\begin{array}{c}-0.022 \\
{[0.031} \\
]\end{array}$ \\
\hline $\begin{array}{l}\text { Mean hourly wage } \\
\text { (2016 dollars) }\end{array}$ & 8.12 & 14.96 & 16.38 & 15.12 & 8.49 & 16.41 & 18.76 & 17.46 & 7.73 & 13.32 & 13.82 & 12.61 \\
\hline $\begin{array}{l}\mathbf{R}^{2} \\
\text { Incremental } \mathbf{R}^{2}\end{array}$ & $\begin{array}{l}0.986 \\
0.003\end{array}$ & $\begin{array}{l}0.995 \\
0.002\end{array}$ & $\begin{array}{l}0.993 \\
0.003\end{array}$ & $\begin{array}{l}0.983 \\
0.003\end{array}$ & $\begin{array}{l}0.978 \\
0.003\end{array}$ & $\begin{array}{l}0.993 \\
0.003\end{array}$ & $\begin{array}{l}0.989 \\
0.004\end{array}$ & $\begin{array}{l}0.967 \\
0.003\end{array}$ & $\begin{array}{l}0.985 \\
0.002\end{array}$ & $\begin{array}{l}0.996 \\
0.002\end{array}$ & $\begin{array}{l}0.993 \\
0.002\end{array}$ & $\begin{array}{l}0.981 \\
0.002\end{array}$ \\
\hline
\end{tabular}

Notes: Data source and other details about the data are described in notes to Figure 5. See notes to Table 1. $\mathrm{N}=1,938$. 
Table 4: OLS and IV Regressions of Log Average Hourly Wage on Log Cohort Share, 19842016, Both Sexes

\begin{tabular}{|c|c|c|c|c|c|c|c|c|}
\hline Estimator & OLS & IV & OLS & IV & OLS & IV & OLS & IV \\
\hline Age & $16-24$ & $16-24$ & $25-49$ & $25-49$ & $50-59$ & $50-59$ & $60-69$ & $60-69$ \\
\hline In(Cohort Size/Pop 16-69) & $\begin{array}{c}0.035 \\
{[0.028]}\end{array}$ & $\begin{array}{l}0.302^{* * *} \\
{[0.090]}\end{array}$ & $\begin{array}{l}0.088^{* *} \\
{[0.042]}\end{array}$ & $\begin{array}{l}0.439^{* * \pi} \\
{[0.118]}\end{array}$ & $\begin{array}{l}-0.004 \\
{[0.027]}\end{array}$ & $\begin{array}{l}0.597^{* * *} \\
{[0.150]}\end{array}$ & $\begin{array}{c}0.021 \\
{[0.042]}\end{array}$ & $\begin{array}{c}-{ }^{-} \\
0.229^{*} \\
{[0.132]}\end{array}$ \\
\hline $\begin{array}{l}\text { IV: In(Cohort Births/Births } \\
\text { 16-29) } \\
\text { Reduced-form coefficient } \\
\text { (dep. var.=In(Average Hourly } \\
\text { Wage)) }\end{array}$ & & $\begin{array}{l}0.084^{* * *} \\
{[0.025]}\end{array}$ & & $\begin{array}{l}0.149^{* * *} \\
{[0.037]}\end{array}$ & & $\begin{array}{l}0 . \\
0.101^{* * *} \\
{[0.020]}\end{array}$ & & $\begin{array}{c}- \\
0.056^{*} \\
{[0.033]}\end{array}$ \\
\hline $\begin{array}{l}\text { Durbin-Wu-Hausman test for } \\
\text { endogeneity ( } p \text {-value) }\end{array}$ & & 0.000 & & 0.000 & & 0.000 & & 0.020 \\
\hline \multicolumn{9}{|l|}{ Men } \\
\hline In(Cohort Size/Pop 16-69) & $\begin{array}{c}0.017 \\
{[0.028]}\end{array}$ & $\begin{array}{l}0.372 \pi \\
{[0.115]}\end{array}$ & $\begin{array}{c}0.045 \\
{[0.040]}\end{array}$ & $\begin{array}{l}0.360^{* * \pi *} \\
{[0.119]}\end{array}$ & $\begin{array}{c}0.014 \\
{[0.026]}\end{array}$ & $\begin{array}{l}-0.587^{* *} \\
{[0.229]}\end{array}$ & $\begin{array}{c}0.043 \\
{[0.050]}\end{array}$ & $\begin{array}{l}-0.167 \\
{[0.155]}\end{array}$ \\
\hline \multicolumn{9}{|l|}{$\begin{array}{l}\text { IV: In(Cohort Births/Births } \\
\text { 16-29) }\end{array}$} \\
\hline $\begin{array}{l}\text { (dep. var.=In(Average Hourly } \\
\text { Wage)) }\end{array}$ & & [0.030] & & [0.041] & & $\begin{array}{l}0.078^{*+4} \\
{[0.023]}\end{array}$ & & [0.043] \\
\hline $\begin{array}{l}\text { Durbin-Wu-Hausman test for } \\
\text { endogeneity ( } p \text {-value) }\end{array}$ & & 0.000 & & 0.000 & & 0.000 & & 0.100 \\
\hline \multicolumn{9}{|l|}{ Women } \\
\hline In(Cohort Size/Pop 16-69) & $\begin{array}{c}0.041 \\
{[0.030]}\end{array}$ & $\begin{array}{l}0.185^{*} \\
{[0.104]}\end{array}$ & $\begin{array}{l}0.055 \\
{[0.042]}\end{array}$ & $\begin{array}{l}0.355^{* *} \\
{[0.138]}\end{array}$ & $\begin{array}{c}0.027 \\
{[0.030]}\end{array}$ & $\begin{array}{l}\overline{-}^{-} \\
0.570^{* * *} \\
{[0.146]}\end{array}$ & $\begin{array}{c}0.008 \\
{[0.038]}\end{array}$ & $\begin{array}{c}- \\
0.332^{*} \\
{[0.179]}\end{array}$ \\
\hline $\begin{array}{l}\text { IV: In(Cohort Births/Births } \\
16-29) \\
\text { Reducd-form coefficient }\end{array}$ & & & & & & & & \\
\hline $\begin{array}{l}\text { Reduced-form coefficient } \\
\text { (dep. var.=In(Average Hourly } \\
\text { Wage)) }\end{array}$ & & $\begin{array}{l}0.053 \\
{[0.030]}\end{array}$ & & $\begin{array}{l}0.112 \\
{[0.042]}\end{array}$ & & $\begin{array}{l}0 . \\
0.106^{* * *} \\
{[0.023]}\end{array}$ & & $\begin{array}{c}- \\
0.065^{*} \\
{[0.034]}\end{array}$ \\
\hline $\begin{array}{l}\text { Durbin-Wu-Hausman test for } \\
\text { endogeneity ( } p \text {-value) }\end{array}$ & & 0.095 & & 0.003 & & 0.000 & & 0.029 \\
\hline
\end{tabular}

Notes: Data source is described in notes to Figure 5. The $1^{\text {st }}$-stage estimates (and F-statistics) are the same as in Table 2. See notes to Table 2 . $\mathrm{N}=1,326$. 
Table 5A: OLS and IV Regressions of Log Labor Force Participation Rate and Hourly Wages of 50 to 59 Year Olds on Log Relative Cohort Sizes for 16 to 24 and 25 to 49 Year Olds, 1984 to 2016, Both Sexes

\begin{tabular}{|c|c|c|c|c|}
\hline Estimator & OLS & IV & OLS & IV \\
\hline Dependent Variable (Logs) & LFP & LFP & $\begin{array}{l}\text { Hourly } \\
\text { Wages }\end{array}$ & $\begin{array}{l}\text { Hourly } \\
\text { Wages }\end{array}$ \\
\hline \multirow[t]{2}{*}{ In(50-59 Cohort Size/16-24 Cohort Size) } & -0.017 & -0.051 & 0.021 & -0.129 \\
\hline & [0.015] & [0.051] & [0.019] & {$[0.086]$} \\
\hline In(50-59 Cohort Size/25-49 Cohort Size) & $\begin{array}{l}0.039^{* *} \\
{[0.016]}\end{array}$ & $\begin{array}{l}0.267^{\star \star \star} \\
{[0.064]}\end{array}$ & $\begin{array}{l}-0.025 \\
{[0.024]}\end{array}$ & $\begin{array}{c}-0.326^{\star \star \star} \\
{[0.108]}\end{array}$ \\
\hline \multicolumn{5}{|l|}{$1^{\text {st }}$-stage F-statistic } \\
\hline (dep. var.=In(50-59 Cohort Size/16-24 Cohort Size)) & & 42.38 & & 42.38 \\
\hline (dep. var. $=\ln (50-59$ Cohort Size/25-49 Cohort Size)) & & 34.60 & & 34.60 \\
\hline \multicolumn{5}{|l|}{ Shea's Partial $\mathbf{R}^{2}$} \\
\hline (dep. var.=In(50-59 Cohort Size/16-24 Cohort Size)) & & 0.04 & & 0.04 \\
\hline (dep. var.=In(50-59 Cohort Size/25-49 Cohort Size)) & & 0.05 & & 0.05 \\
\hline Durbin-Wu-Hausman test for endogeneity ( $p$-value) & & 0.000 & & 0.000 \\
\hline \multicolumn{5}{|l|}{ Men } \\
\hline \multirow[t]{2}{*}{ In(50-59 Cohort Size/16-24 Cohort Size) } & $-0.026^{* *}$ & -0.089 & 0.025 & -0.203 \\
\hline & [0.013] & [0.075] & {$[0.020]$} & [0.144] \\
\hline \multirow[t]{2}{*}{ In(50-59 Cohort Size/25-49 Cohort Size) } & $0.029^{* *}$ & $0.192^{* * *}$ & -0.015 & $-0.349^{* * *}$ \\
\hline & [0.015] & [0.068] & [0.023] & {$[0.131]$} \\
\hline \multicolumn{5}{|l|}{$1^{\text {st }}$-stage F-statistic } \\
\hline (dep. var.=In(50-59 Cohort Size/16-24 Cohort Size)) & & 17.12 & & 17.12 \\
\hline (dep. var.=In(50-59 Cohort Size/25-49 Cohort Size)) & & 26.12 & & 26.12 \\
\hline \multicolumn{5}{|l|}{ Shea's Partial $\mathbf{R}^{2}$} \\
\hline (dep. var.=In(50-59 Cohort Size/16-24 Cohort Size)) & & -0.03 & & -0.03 \\
\hline (dep. var.=In(50-59 Cohort Size/25-49 Cohort Size)) & & 0.01 & & 0.01 \\
\hline Durbin-Wu-Hausman test for endogeneity ( $p$-value) & & 0.000 & & 0.000 \\
\hline \multicolumn{5}{|l|}{ Women } \\
\hline \multirow[t]{2}{*}{ In(Cohort Size/16-24 Cohort Size) } & -0.020 & 0.004 & 0.014 & -0.108 \\
\hline & {$[0.020]$} & [0.081] & [0.021] & {$[0.091]$} \\
\hline \multirow[t]{2}{*}{ In(Cohort Size/25-49 Cohort Size) } & $0.075^{\star \star \star}$ & $0.420^{* * *}$ & 0.006 & $-0.334^{\star \star *}$ \\
\hline & {$[0.025]$} & {$[0.105]$} & [0.026] & {$[0.117]$} \\
\hline \multicolumn{5}{|l|}{$1^{\text {st }}$-stage F-statistic } \\
\hline (dep. var.=In(50-59 Cohort Size/16-24 Cohort Size)) & & 42.55 & & 42.55 \\
\hline (dep. var.=In(50-59 Cohort Size/25-49 Cohort Size)) & & 35.69 & & 35.69 \\
\hline \multicolumn{5}{|l|}{ Shea's Partial $\mathbf{R}^{2}$} \\
\hline (dep. var. $=\ln (50-59$ Cohort Size/16-24 Cohort Size)) & & 0.03 & & 0.03 \\
\hline (dep. var.=In(50-59 Cohort Size/25-49 Cohort Size)) & & 0.02 & & 0.02 \\
\hline Durbin-Wu-Hausman test for endogeneity ( $p$-value) & & 0.000 & & 0.000 \\
\hline
\end{tabular}

Notes: Data source is described in notes to Figures 1,2, and 5, and specification details are described in notes to Table 1. The table reports estimates of equation (2). Regression weighted by average state population through the sample period. Uses Newey-West standard errors to account for heteroskedasticity and autocorrelation. ${ }^{*},{ }^{* *}$, and ${ }^{* * *}$ denotes $0.1,0.05$, and 0.01 significance. The two instrumental variables used are the total number of births for 50-59 year-olds divided by the total number of births for 16-24 year-olds by state and year and the total number of births for 50-59 year-olds divided by the total number of births for the 25-49 year-olds by state and year. We exclude certain years and states with missing birth data for the cohorts, as only a handful of states started reporting births in 1915. $\mathrm{N}=1,326$. Note that we could use more observations in this table than in Table 5B, for 60-69 year-olds, because the absence of early birth data is less of a constraint. However, we keep the samples the same in the two tables to make the estimates most comparable. 
Table 5B: OLS and IV Regressions of Log Labor Force Participation Rate and Hourly Wages of 60 to 69 Year Olds on Log Relative Cohort Sizes for 16 to 24 and 25 to 49 Year-Olds, 1984 to 2016, Both Sexes

\begin{tabular}{|c|c|c|c|c|}
\hline Estimator & OLS & IV & OLS & IV \\
\hline Dependent Variable (Logs) & LFP & LFP & Hourly Wages & $\begin{array}{l}\text { Hourly } \\
\text { Wages }\end{array}$ \\
\hline In(60-69 Cohort Size/16-24 Cohort Size) & $\begin{array}{l}-0.125 \\
{[0.038]}\end{array}$ & $\begin{array}{l}-0.462 \\
{[0.107]}\end{array}$ & $\begin{array}{c}0.023 \\
{[0.033]}\end{array}$ & $\begin{array}{l}-0.248^{* *} \\
{[0.101]}\end{array}$ \\
\hline $\begin{array}{l}\text { In(60-69 Cohort Size/25-49 Cohort Size) } \\
1^{\text {st }} \text {-stage F-statistic }\end{array}$ & $\begin{array}{l}0.081^{*} \\
{[0.045]}\end{array}$ & $\begin{array}{l}0.665^{* \star *} \\
{[0.139]}\end{array}$ & $\begin{array}{l}-0.006 \\
{[0.045]}\end{array}$ & $\begin{array}{l}-0.113 \\
{[0.127]}\end{array}$ \\
\hline (dep. var. $=\ln (60-69$ Cohort Size/16-24 Cohort Size)) & & 54.17 & & 54.17 \\
\hline $\begin{array}{l}\text { (dep. var. }=\ln (60-69 \text { Cohort Size/25-49 Cohort Size)) } \\
\text { Shea's Partial R }\end{array}$ & & 49.35 & & 49.35 \\
\hline (dep. var. $=\ln (60-69$ Cohort Size/16-24 Cohort Size)) & & 0.09 & & 0.09 \\
\hline (dep. var.=In(60-69 Cohort Size/25-49 Cohort Size)) & & 0.09 & & 0.09 \\
\hline Durbin-Wu-Hausman test for endogeneity ( $p$-value) & & 0.000 & & 0.000 \\
\hline \multicolumn{5}{|l|}{ Men } \\
\hline In(60-69 Cohort Size/16-24 Cohort Size) & $\begin{array}{l}-0.070 * \\
{[0.035]}\end{array}$ & $\begin{array}{l}-0.470 \\
{[0.115]}\end{array}$ & $\begin{array}{c}0.032 \\
{[0.037]}\end{array}$ & $\begin{array}{l}-0.313^{n+1} \\
{[0.137]}\end{array}$ \\
\hline In(60-69 Cohort Size/25-49 Cohort Size) & $\begin{array}{c}0.031 \\
{[0.039]}\end{array}$ & $\begin{array}{l}0.511^{* * *} \\
{[0.133]}\end{array}$ & $\begin{array}{c}0.010 \\
{[0.048]}\end{array}$ & $\begin{array}{l}-0.057 \\
{[0.146]}\end{array}$ \\
\hline $\begin{array}{l}1^{\text {st }} \text {-stage F-statistic } \\
\text { (dep. var.=In(60-69 Cohort Size/16-24 Cohort Size)) }\end{array}$ & & 43.71 & & 43.71 \\
\hline $\begin{array}{l}\text { (dep. var. }=\ln (60-69 \text { Cohort Size/25-49 Cohort Size)) } \\
\text { Shea's Partial R }\end{array}$ & & 57.98 & & 57.98 \\
\hline (dep. var.=In(60-69 Cohort Size/16-24 Cohort Size)) & & 0.03 & & 0.03 \\
\hline (dep. var.=In(60-69 Cohort Size/25-49 Cohort Size)) & & 0.07 & & 0.07 \\
\hline Durbin-Wu-Hausman test for endogeneity ( $p$-value) & & 0.000 & & 0.000 \\
\hline Women & & & & \\
\hline In(60-69 Cohort Size/16-24 Cohort Size) & $\begin{array}{l}-0.126 \\
{[0.045]}\end{array}$ & $\begin{array}{l}-0.508 \\
{[0.164]}\end{array}$ & $\begin{array}{c}-0.042 \\
{[0.033]}\end{array}$ & $\begin{array}{l}-0.236 \\
{[0.116]}\end{array}$ \\
\hline In(60-69 Cohort Size/25-49 Cohort Size) & $\begin{array}{l}0.136^{* *} \\
{[0.055]}\end{array}$ & $\begin{array}{l}0.947^{* \star *} \\
{[0.246]}\end{array}$ & $\begin{array}{c}0.055 \\
{[0.045]}\end{array}$ & $\begin{array}{l}-0.163 \\
{[0.163]}\end{array}$ \\
\hline $\begin{array}{l}1^{\text {st }} \text {-stage F-statistic } \\
\text { (dep. var.=In(60-69 Cohort Size/16-24 Cohort Size)) }\end{array}$ & & 38.20 & & 38.20 \\
\hline $\begin{array}{l}\text { (dep. var.=In(60-69 Cohort Size/25-49 Cohort Size)) } \\
\text { Shea's Partial } R^{2}\end{array}$ & & 22.17 & & 22.17 \\
\hline (dep. var.=In(60-69 Cohort Size/16-24 Cohort Size)) & & 0.05 & & 0.05 \\
\hline (dep. var.=In(60-69 Cohort Size/25-49 Cohort Size)) & & 0.02 & & 0.02 \\
\hline Durbin-Wu-Hausman test for endogeneity ( $p$-value) & & 0.000 & & 0.002 \\
\hline
\end{tabular}

Notes: Data source is described in notes to Figures 1, 2, and 5, and specification details are described in notes to Table 1. The table reports estimates of equation (2). Regression weighted by average state population through the sample period. Uses Newey-West standard errors to account for heteroskedasticity and autocorrelation. ${ }^{*},{ }^{* *}$, and ${ }^{* * *}$ denotes $0.1,0.05$, and 0.01 significance. The two instrumental variables used are the total number of births for $60-69$ year-olds divided by the total number of births for 16-24 year-olds by state and year and the total number of births for 60-69 year-olds divided by the total number of births for the 25-49 year-olds by state and year. We exclude certain years and states with missing birth data for the cohorts, as only a handful of states started reporting births in 1915 . N $=1,326$. 
Table 6: Summary of Evidence on Relationship between Relative Cohort Size, and

LFP Rates and Wages

\begin{tabular}{|c|c|c|c|c|}
\hline Type of evidence & $16-24$ & $25-49$ & $50-59$ & $60-69$ \\
\hline \multicolumn{5}{|l|}{ LFP } \\
\hline \multicolumn{5}{|l|}{ OLS (Table 1) } \\
\hline Men and women & $+t^{* * *}$ & $+* *$ & $+t^{* * *}$ & $--^{* \star \star}$ \\
\hline Expected bias & Positive & Positive & $?$ & Negative \\
\hline \multicolumn{5}{|l|}{ IV (Table 2) } \\
\hline Men and women & $--^{* *}$ & $--^{* * *}$ & $+{ }^{* * *}$ & $+t^{* * *}$ \\
\hline $\begin{array}{l}\text { Consistent with supply effect } \\
\text { of relative cohort size? }\end{array}$ & Yes & Yes & No & No \\
\hline \multicolumn{5}{|l|}{$\begin{array}{l}\text { IV, relative to two younger } \\
\text { cohorts (Tables } 5 A, 5 B \text { ) }\end{array}$} \\
\hline \multicolumn{5}{|l|}{ Men and women } \\
\hline /16-24 & $\ldots$ & $\ldots$ & - & $-{ }^{*}$ \\
\hline $\begin{array}{l}\text { Consistent with supply effect } \\
\text { of relative cohort size? }\end{array}$ & $\cdots$ & $\cdots$ & Yes & Yes \\
\hline $125-49$ & $\ldots$ & $\ldots$ & $++^{* * \star}$ & $++^{* * \pi}$ \\
\hline $\begin{array}{l}\text { Consistent with supply effect } \\
\text { of relative cohort size? }\end{array}$ & $\cdots$ & $\cdots$ & No & No \\
\hline \multicolumn{5}{|l|}{ Wages } \\
\hline \multicolumn{5}{|l|}{ OLS (Table 3) } \\
\hline Men and women & $-^{* *}$ & $+{ }^{* \star * \pi}$ & $-^{* \star}$ & - \\
\hline Expected bias & Positive & Positive & None (?) & None \\
\hline \multicolumn{5}{|l|}{ IV (Table 4) } \\
\hline Men and women & $+{ }^{* * \pi}$ & $+t^{* \pi}$ & $-{ }^{* *}$ & $-{ }^{*}$ \\
\hline $\begin{array}{l}\text { Consistent with supply effect } \\
\text { of relative cohort size? }\end{array}$ & No & No & Yes & Yes \\
\hline \multicolumn{5}{|l|}{$\begin{array}{l}\text { IV, relative to two younger } \\
\text { cohorts (Tables } 5 \mathrm{~A}, 5 \mathrm{~B} \text { ) }\end{array}$} \\
\hline \multicolumn{5}{|l|}{$116-24$} \\
\hline Men and women & $\ldots$ & $\ldots$ & - & $--^{* *}$ \\
\hline $\begin{array}{l}\text { Consistent with supply effect } \\
\text { of relative cohort size? }\end{array}$ & $\cdots$ & $\cdots$ & Yes & Yes \\
\hline \multicolumn{5}{|l|}{$125-49$} \\
\hline Men and women & $\ldots$ & $\ldots$ & $--^{* * *}$ & - \\
\hline $\begin{array}{l}\text { Consistent with supply effect } \\
\text { of relative cohort size? }\end{array}$ & $\cdots$ & $\ldots$ & Yes & No \\
\hline
\end{tabular}

Notes: Uses Newey-West standard errors to account for heteroskedasticity and autocorrelation. ${ }^{*},{ }^{* *}$, and ${ }^{* * *}$ denotes $0.1,0.05$, and 0.01 significance. $\mathrm{N}=1,326$. 
Table 7: IV Regressions of Part-time Work and Self-Employment of Older, 1984-2016, Both Sexes

\begin{tabular}{|c|c|c|c|c|c|c|c|c|}
\hline \multirow{2}{*}{$\begin{array}{l}\text { Older Cohort } \\
\text { Dependent Variable, Log(·/Labor } \\
\text { Force) }\end{array}$} & \multicolumn{4}{|c|}{ 50-59 Year-olds } & \multicolumn{4}{|c|}{ 60-69 Year-olds } \\
\hline & $\begin{array}{l}\text { Part- } \\
\text { time }\end{array}$ & $\begin{array}{l}\text { Self- } \\
\text { employe } \\
\text { d }\end{array}$ & $\begin{array}{l}\text { Self- } \\
\text { employed, } \\
\text { incorporate } \\
\text { d }\end{array}$ & $\begin{array}{l}\text { Self- } \\
\text { employed, } \\
\text { unincorporat } \\
\text { ed }\end{array}$ & $\begin{array}{l}\text { Part- } \\
\text { time }\end{array}$ & $\begin{array}{l}\text { Self- } \\
\text { employe } \\
\text { d }\end{array}$ & $\begin{array}{l}\text { Self- } \\
\text { employed, } \\
\text { incorporat } \\
\text { ed }\end{array}$ & $\begin{array}{l}\text { Self- } \\
\text { employed, } \\
\text { unincorporat } \\
\text { ed }\end{array}$ \\
\hline $\begin{array}{l}\text { In(Older Cohort Size/16-24 Cohort } \\
\text { Size) }\end{array}$ & $\begin{array}{l}0.278 \\
{[0.220]}\end{array}$ & $\begin{array}{l}0.523^{*} \\
{[0.275]}\end{array}$ & $\begin{array}{l}-0.345 \\
{[0.363]}\end{array}$ & $\begin{array}{l}0.742^{*} \\
{[0.380]}\end{array}$ & $\begin{array}{l}0.095 \\
{[0.159]}\end{array}$ & $\begin{array}{l}0.056 \\
{[0.197]}\end{array}$ & $\begin{array}{l}0.154 \\
{[0.403]}\end{array}$ & $\begin{array}{l}0.010 \\
{[0.250]}\end{array}$ \\
\hline $\begin{array}{l}\text { In(OIder Cohort Size/25-49 Cohort } \\
\text { Size) }\end{array}$ & $\begin{array}{l}0.360 \\
{[0.235]}\end{array}$ & $\begin{array}{l}1.023^{* * *} \\
{[0.330]}\end{array}$ & $\begin{array}{l}0.230 \\
{[0.410]}\end{array}$ & $\begin{array}{l}1.321^{* * *} \\
{[0.467]}\end{array}$ & $\begin{array}{l}0.553^{* *} \\
{[0.224]}\end{array}$ & $\begin{array}{l}0.093 \\
{[0.256]}\end{array}$ & $\begin{array}{l}0.722 \\
{[0.565]}\end{array}$ & $\begin{array}{l}-0.052 \\
{[0.330]}\end{array}$ \\
\hline
\end{tabular}

Notes: Notes from Tables 5A and 5B apply. Part-time and self-employed come from different questions and are not mutually exclusive. Part-time and selfemployment status are based on current employment only. 
Table 8: OLS Regressions of Log Average Hourly Wages on Log Part-Time and Self-Employed Workforce Shares, 1984 to 2016, Both Sexes

\begin{tabular}{|c|c|c|c|c|c|c|c|c|}
\hline \multirow[b]{2}{*}{$\begin{array}{l}\text { Older Cohort } \\
\text { Independent Variables, Shares of } \\
\text { Employed Workforce (Logs) }\end{array}$} & \multicolumn{4}{|c|}{ 50-59 Year-olds } & \multicolumn{4}{|c|}{ 60-69 Year-olds } \\
\hline & Part-time & $\begin{array}{l}\text { Self- } \\
\text { employe } \\
\text { d }\end{array}$ & $\begin{array}{c}\text { Self- } \\
\text { employed, } \\
\text { incorporate } \\
\text { d }\end{array}$ & $\begin{array}{l}\text { Self- } \\
\text { employed, } \\
\text { unincorporat } \\
\text { ed }\end{array}$ & $\begin{array}{l}\text { Part- } \\
\text { time }\end{array}$ & $\begin{array}{l}\text { Self- } \\
\text { employe } \\
\text { d }\end{array}$ & $\begin{array}{c}\text { Self- } \\
\text { employed, } \\
\text { incorporat } \\
\text { ed }\end{array}$ & $\begin{array}{l}\text { Self- } \\
\text { employed, } \\
\text { unincorporat } \\
\text { ed }\end{array}$ \\
\hline $\begin{array}{l}\text { Regression for part-time and } \\
\text { for self-employed }\end{array}$ & $\begin{array}{l}-0.063^{* * *} \\
{[0.012]}\end{array}$ & $\begin{array}{c}0.000 \\
{[0.010]}\end{array}$ & $\ldots$ & $\ldots$ & $\begin{array}{l}-0.125^{\star \star \star} \\
{[0.020]}\end{array}$ & $\begin{array}{l}-0.005 \\
{[0.015]}\end{array}$ & $\ldots$ & $\ldots$ \\
\hline $\begin{array}{l}\text { Regression for part-time, } \\
\text { for self-employed incorporated, } \\
\text { and } \\
\text { self-employed unincorporated }\end{array}$ & $\begin{array}{l}-0.063^{* * *} \\
{[0.012]}\end{array}$ & $\cdots$ & $\begin{array}{c}0.002 \\
{[0.006]}\end{array}$ & $\begin{array}{c}0.001 \\
{[0.008]}\end{array}$ & $\begin{array}{l}-0.125^{* * *} \\
{[0.019]}\end{array}$ & $\cdots$ & $\begin{array}{c}0.010 \\
{[0.008]}\end{array}$ & $\begin{array}{l}-0.015 \\
{[0.011]}\end{array}$ \\
\hline
\end{tabular}

Notes: Notes from Tables 5A and 5B apply. Each row reports results from two separate regressions for log average hourly wages, for 50-59 year-olds or 60-69 year-olds. 
Appendix Figure A1: One-year Interstate In-Migration of 60 to 69 Year Olds for Retirement-Related and Work-Related Reasons, as Percent of 60- to 69-Year-Old Population, 2008 to 2016

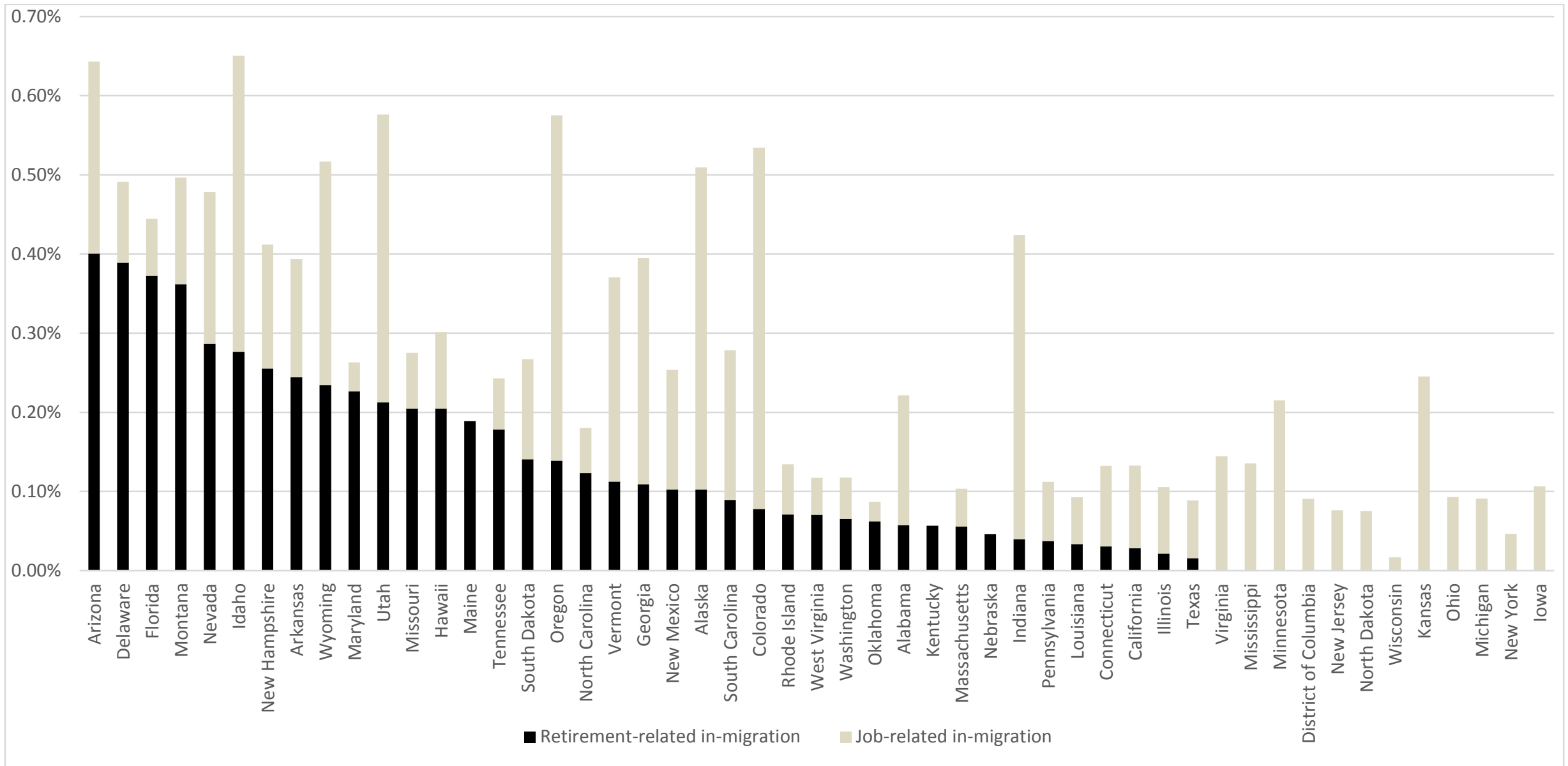

Notes: Based on CPS Annual Social and Economic Supplement (ASEC) data, 2008-2016. Data are constructed using survey weights. 
Appendix Figure A2: One-year Interstate In-Migration of 50 to 59 Year Olds for Retirement-Related and Work-Related Reasons, as Percent of 50- to 59Year-Old Population, 2008 to 2016

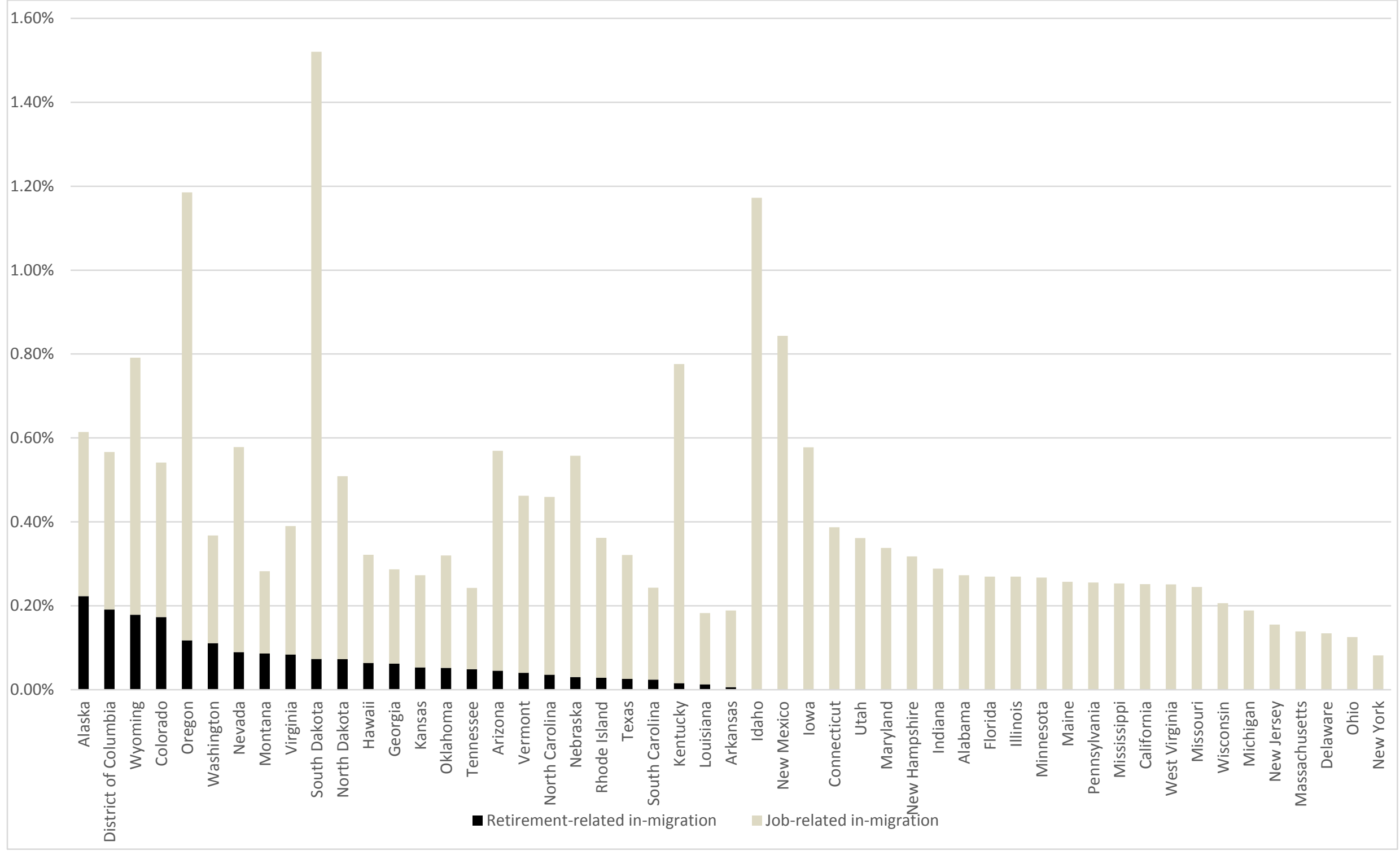

Notes: Based on CPS Annual Social and Economic Supplement (ASEC) data, 2008-2016. Data are constructed using survey weights. 
Appendix Figure A3: One-year Interstate In-Migration of 25 to 49 Year Olds for Retirement-Related and Work-Related Reasons, as Percent of 25- to 49Year-Old Population, 2008 to 2016

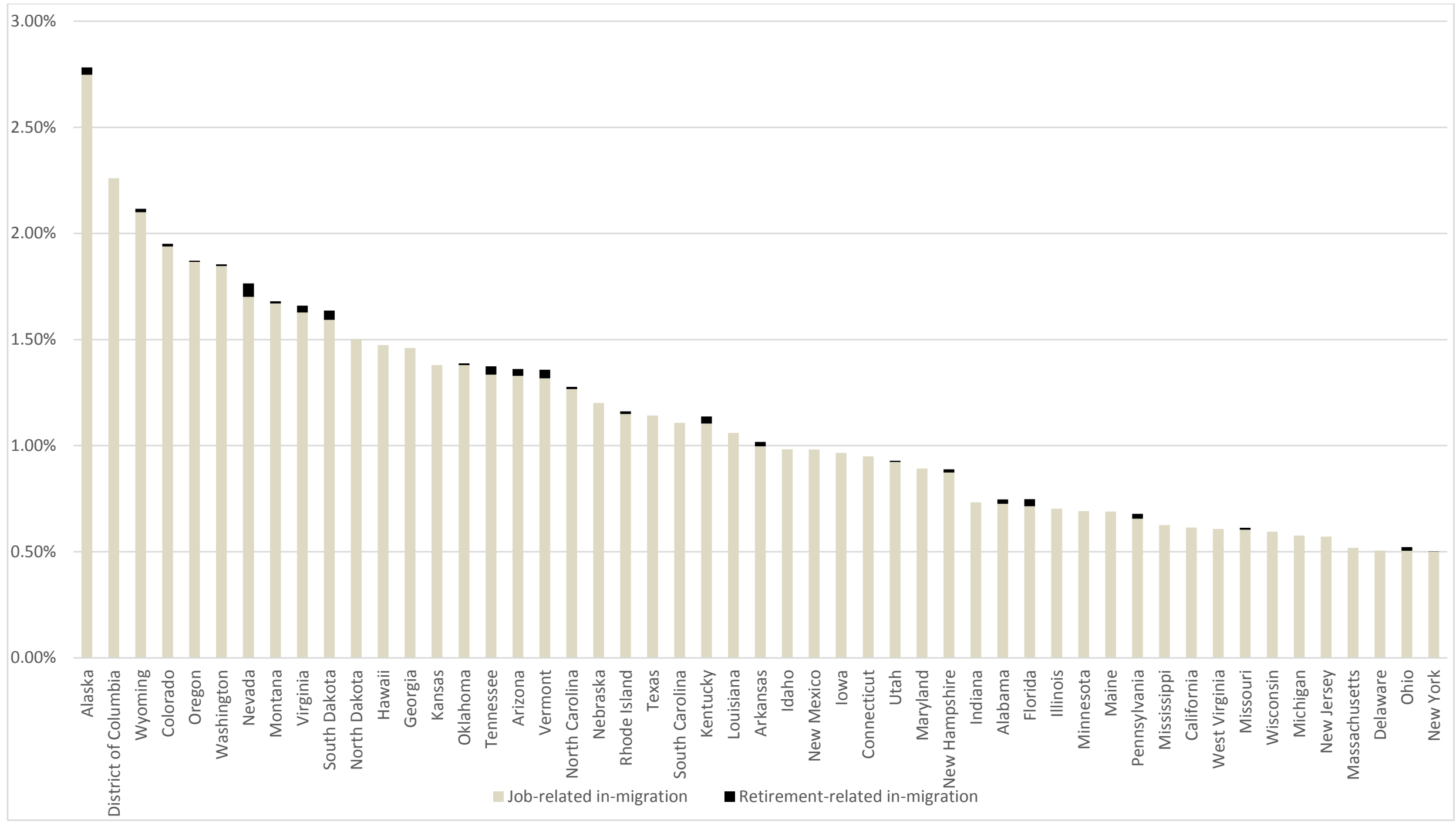

Notes: Based on CPS Annual Social and Economic Supplement (ASEC) data, 2008-2016. Data are constructed using survey weights. 
Appendix Figure A4: One-year Interstate In-Migration of 16 to 24 Year Olds for Retirement-Related and Work-Related Reasons, as Percent of 16- 24-Year-Old Population, 2008 to 2016

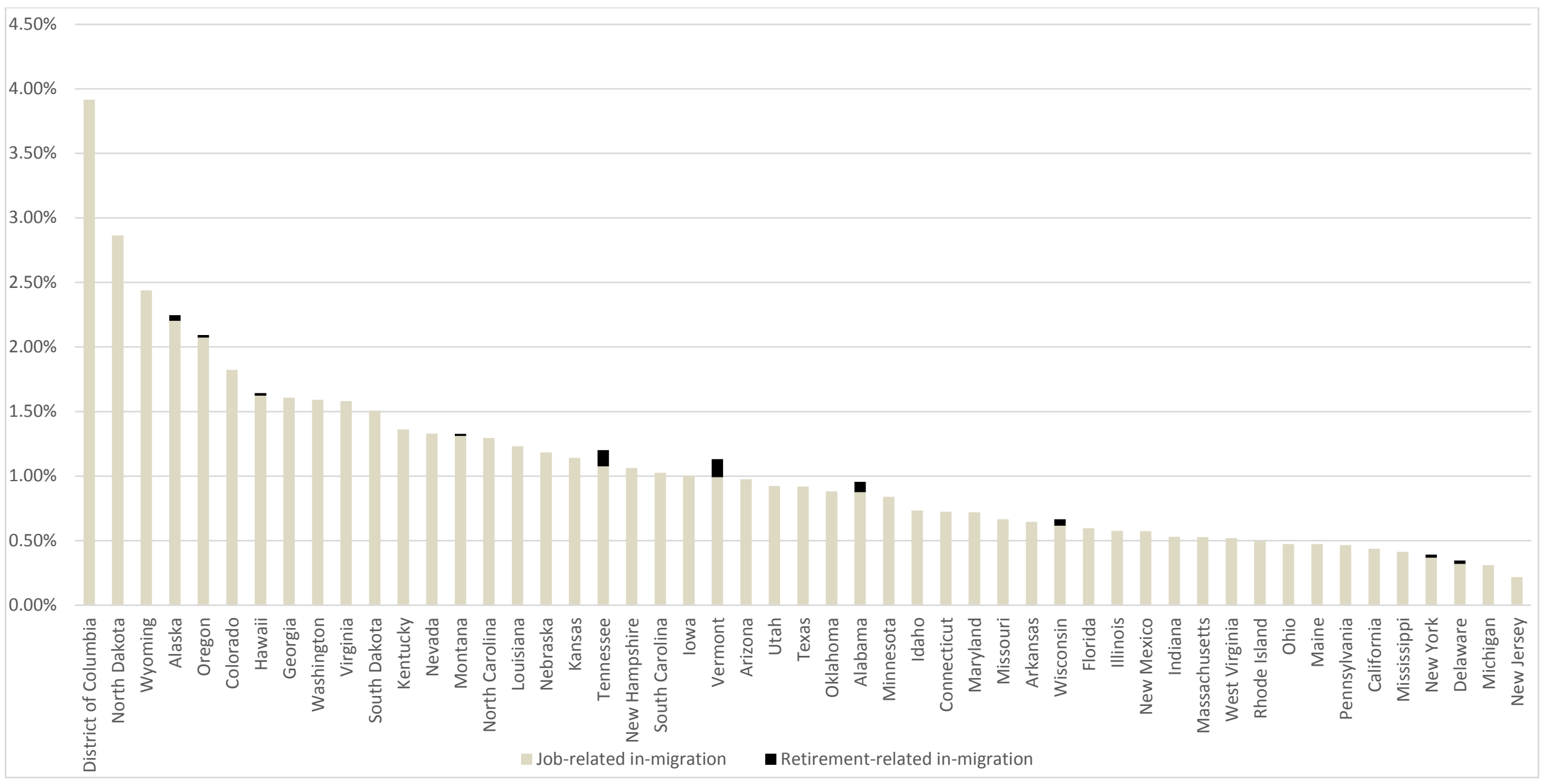

Notes: Based on CPS Annual Social and Economic Supplement (ASEC) data, 2008-2016. Data are constructed using survey weights. 


\section{Appendix Table A: Percent Retired within Age Group, 2012-2017}

\begin{tabular}{l|c}
\hline Age Group & Percentage Retired \\
\hline $\mathbf{1 6 - 2 4}$ & $0.26 \%$ \\
\hline $\mathbf{2 5 - 4 9}$ & $0.81 \%$ \\
\hline $\mathbf{5 0 - 5 9}$ & $6.14 \%$ \\
\hline $\mathbf{6 0 - 6 9}$ & $40.94 \%$ \\
\hline
\end{tabular}

Source: Census Population Survey (CPS) 2012-2017. The percentage retired is computed from the employment status question, which captures respondents saying that they are not in the labor force due to retirement.

\section{Appendix Table B: Dates States Joined the Birth Registration System}

\begin{tabular}{|c|c|c|c|}
\hline 1915 & 1916 & 1917 & 1919 \\
\hline $\begin{array}{l}\text { Connecticut } \\
\text { District of Columbia } \\
\text { Maine } \\
\text { Massachusetts } \\
\text { Michigan } \\
\text { Minnesota } \\
\text { New Hampshire } \\
\text { New York } \\
\text { Pennsylvania } \\
\text { Rhode Island } \\
\text { Vermont }\end{array}$ & Maryland & $\begin{array}{l}\text { Indiana } \\
\text { Kansas } \\
\text { Kentucky } \\
\text { North Carolina } \\
\text { Ohio } \\
\text { Utah } \\
\text { Virginia } \\
\text { Washington } \\
\text { Wisconsin }\end{array}$ & $\begin{array}{l}\text { California } \\
\text { Oregon } \\
\text { South Carolina }\end{array}$ \\
\hline 1920 & 1921 & 1922 & 1924 \\
\hline Nebraska & $\begin{array}{l}\text { Delaware } \\
\text { Mississippi } \\
\text { New Jersey }\end{array}$ & $\begin{array}{l}\text { Illinois } \\
\text { Montana } \\
\text { Wyoming }\end{array}$ & $\begin{array}{l}\text { Florida } \\
\text { lowa } \\
\text { North Dakota }\end{array}$ \\
\hline 1925 & 1926 & 1927 & 1928 \\
\hline West Virginia & $\begin{array}{l}\text { Arizona } \\
\text { Idaho }\end{array}$ & $\begin{array}{l}\text { Alabama } \\
\text { Arkansas } \\
\text { Louisiana } \\
\text { Missouri } \\
\text { Tennessee }\end{array}$ & $\begin{array}{l}\text { Colorado } \\
\text { Georgia } \\
\text { Oklahoma }\end{array}$ \\
\hline 1929 & 1931 & 1932 & 1933 \\
\hline $\begin{array}{l}\text { Nevada } \\
\text { New Mexico }\end{array}$ & Hawaii $^{* * *}$ & South Dakota & Texas \\
\hline \multicolumn{4}{|l|}{1945} \\
\hline Alaska & & & \\
\hline
\end{tabular}

Source: National Center for Health Statistics $(1947,1968)$.

* Rhode Island disappeared from the birth registration for 1919 and 1920.

** South Carolina disappeared from the birth registration for 1925-1927.

${ }^{* * *}$ Hawaii had number of births from individual U.S. Vital Statistics Reports in 1931 as a territorial supplement but does not report crude birth rates until 1950. 